\title{
Cancer, Photodynamic Therapy and Porphyrin-Type Derivatives
}

\author{
ANA T.P.C. GOMES, MARIA G.P.M.S. NEVES and JOSÉ A.S. CAVALEIRO \\ Química Orgânica, Produtos Naturais e Agroalimentares/QOPNA Research Unit and Department \\ of Chemistry, University of Aveiro, University Campus, 3810-193 Aveiro, Portugal
}

Manuscript received on October 10, 2017; accepted for publication on December 1, 2017

\begin{abstract}
This review has two parts. The first one gives an approach to interdisciplinary studies against cancer carried out by many scientists using porphyrin-type substrates as photosensitizers in PDT. Intensive studies were performed for almost six decades. The successes really started in 1993 with the first formulation patented under the trade name Photofrin, which was immediately approved in several countries to treat certain types of cancer. Photofrin is still used although certain negative features soon became well known. That has motivated the search for better new photosensitizers. Several ones were developed, evaluated and a few of them had clinical approval. This group includes porphyrin derivatives and pro-drugs (aminolevulinic acid and its alkyl esters). Oncological, dermatological and ophthalmic applications are now taking place for the benefit of mankind. The second part of this review is related with the work carried out in Aveiro at the authors University on the synthesis and biological evaluation of several potential PDT photosensitizers. Not only new synthetic methodologies mainly for porphyrins and chlorins were developed but also other related macrocycles of the phthalocyanine and corrole types have entered in the same "pipeline". In vivo and in vitro biological evaluations also took place under interdisciplinary studies.
\end{abstract}

Key words: Cancer, Photodynamic Therapy, Porphyrins, Chlorins, Related macrocycles.

\section{INTRODUCTION}

Porphyrin-type compounds play in Nature vital functions. How would be Life on Earth without respiration, photosynthesis, drug detoxification, etc? These and other biologically ruling phenomena would not be possible without the intervention of

Correspondence to: Ana Gomes

E-mail: ana.peixoto@ua.pt

José Cavaleiro

E-mail: jcavaleiro@ua.pt

* Contribution to the centenary of the Brazilian Academy of Sciences. porphyrin-like macrocycles. It has to be mentioned at this moment that the literature data about the development and applications of such type of compounds is really impressive; however in this publication only a few significant references are chosen but with them the reader can have a clear idea about the topic.

In the absence of such compounds our Life would be different from the one we have. This vital action certainly called the attention of scientists, who along centuries, have been determined to understand our World. The colors of blood and green leaves might have also contributed for such 
interest (Drabkin 1978, Milgrom 1997). Special and decisive moments from the past are: a) in 1747 Menghini was able to show that blood contains iron; b) in 1841 Scherer reported the isolation of the iron-free pigment from blood; c) in 1864 Hoppe-Seyler put forward the name hemoglobin and in the following years the same scientist was able to demonstrate that porphyrins isolated from blood are pyrrolic pigments and also that heme and chlorophyll are structurally similar. On the synthetic approaches field, since the 1920s, several methodologies leading to porphyrin derivatives have been work targets of several scientists. Hans Fischer and his Munich group in 1929 reported the synthesis of protoporphyrin IX (Fig. 1) and its Fe(III) chloride complex (hemin). This was a landmark in the porphyrin area which demonstrated the real tetrapyrrolic structure of porphyrins; mainly due to such work the Nobel prize was awarded to Fischer in the following year. In 1960 Kendrew and Perutz reported the X-ray structures of the hemoproteins responsible for our respiration, the myoglobin and hemoglobin. Two years later they were also awarded the Nobel prize (Sheldon 1994).

After the end of the $2^{\text {nd }}$ World War scientists in Europe, America and Japan were deeply concerned not only with the discovery of new and efficient synthetic routes but also with the mode of action, biosynthesis and catabolism of porphyrins of biological significance. The Cytochromes P450, catalases and peroxidases became known, and mimics ofsuchenzymesstartedtobeconsidered. This has originated a great deal of work on the potential applications of derivatives containing macrocycles of the porphyrin, chlorin (dihydroporphyrin) and bacteriochlorin (tetrahydroporphyrin) types (Fig. 2). It has been well established that porphyrin-type compounds can have applications in several fields and devices, like solar cells and electron transfer processes, as oxidative catalysts, (Sheldon 1994, Simões et al. 2016) as sensors, (Paolesse et al. 2017) semiconductors and superconductors, (Jian et al. 1998) liquid crystals, (Kumar and Kumar 2017) biocides (fungicides and insecticides) (Carré et al. 1999, Amor et al. 1998) but significantly it is in Medicine, acting against cancer cells (photodynamic therapy - PDT) and more recently in the photo-inactivation of microorganisms (photodynamic inactivation - PDI), that such compounds can contribute for a better life to human beings (Bonnett 2000, Almeida et al. 2011).

\section{HISTORICAL FEATURES OF PHOTODYNAMIC THERAPY}

From ancient times that humans considered the application of solar radiations (phototherapy) for medicinal cures. Forty centuries ago Pharaoh Akhnaton used to consider Sun as the only God and all goodness was due to it. Akhnaton had successors in such approach of life. Hippocrates Asclepiades, a Greek physician of the Age of Pericles, considered as one of the most outstanding figures in the history of medicine, supported the use of sunlight to recover from muscle atrophies (Emerson 1933). Another slightly different approach was also considered in ancient times to treat vitiligo (a skin loss of pigmentation) via the oral administration of extracts of Psoralea corylifolia, which contains furocoumarins, followed by sunlight exposure; this can be considered as a case of photochemotherapy (Emerson 1933, Bonnett 1999, Roelandts 2002).

The use of visible light as a free agent demonstrating therapeutic effects was looked with apprehensive thoughts. But new phototherapy developments came up in higher scientific ways due to a Danish scientist, Niels Finsen (Nobel prize in 1903), who treated lupus vulgaris, a cutaneous tuberculosis skin lesion with nodular appearance, with sunlight. There was a great enthusiasm for phototherapy and Queen Alexandra (wife a King Edward VII), who was also Danish and President of the London Hospital, brought the technology to London. A great Light Department with a carbon 


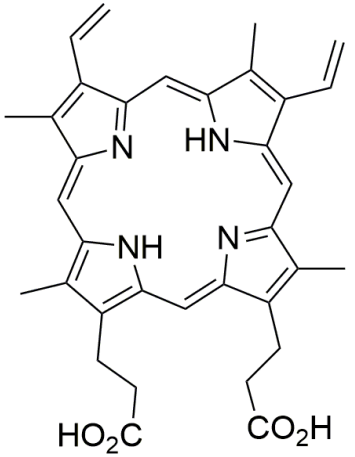

Figure 1 - Structure of Protoporphyrin IX.

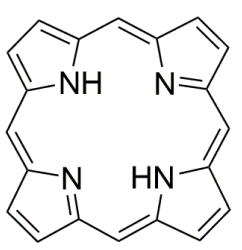

A

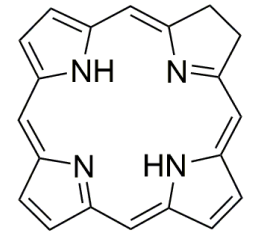

B

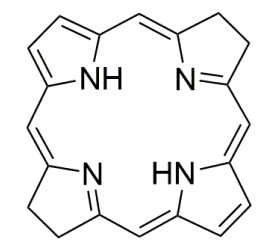

C
Figure 2 - Porphyrin (A), Chlorin (B) and Bacteriochlorin (C) macrocycles.

arc as the light source was set up at the hospital. Although with such high support phototherapy did not have a big development. That presumably was due to a prevailing skepticism and to a diminution of lupus vulgaris that was being treated by this phototherapy approach. However phototherapy had significant revival with diseases like rickets, psoriasis, neonatal hyperbilirubinemia and cancer which contributed to the fantastic significance of phototherapy.

Cancer diseases are recognized as being as the second reason of death in the world. Because of that, especially from the beginning of the $\mathrm{XX}$ century, many scientists have been looking for finding adequate solutions for such terrific diseases. For the benefit of mankind certain landmarks of such research became well known. To mention just a few it can be said that in 1910 Hausmann using mice exposed to light demonstrated the effect of hematoporphyrin (Fig. 3) and light on red blood cells; in 1913 Meyer-Betz brought the first report of human photosensitization; he injected himself with $200 \mathrm{mg}$ of hematoporphyrin and subsequently had pain and swelling in the light-exposed areas. A few years later (1924) Policard reported his studies on porphyrin fluorescence localization in rat sarcoma with UV light illumination. The idea of cancer detection could be envisaged already at that time. Other scientists have continued to develop such type of studies and Auler and Banzer, in 1942, demonstrated the localization of exogenously administrated porphyrins in malignant tumors with also a certain degree of photonecrosis. Such promising properties of porphyrins were again put in evidence in vivo by Figge and collaborators in 1948 with studies with mice containing induced and transplanted tumors; by fluorescence techniques porphyrin localization was observed in each tumor. Other studies from the same group were then extended to patients; intravenous administration of hematoporphyrin dihydrochloride to patients with benign and malign lesions, under the action of adequate radiation, allowed the cancer detection by fluorescence observation. By the 1960s it was clearly demonstrated the potential significance of the use of porphyrin-type compounds to localize and to fight cancer malignancies (Bonnett 1995, Juarranz et al. 2008, Marcus 1992, Lipson et al. 1961, Denis and Hamblin 2013).

It was again demonstrated that hematoporphyrin and hematoporphyrin derivatives could be used in a tumor diagnostic way. Such phototherapy is now known as photodynamic therapy (PDT) since the destruction of living cells is due to the simultaneous action of a radiation with adequate wavelength, oxygen and administered compound. Photodynamic therapy of cancer is then a way to remove ill cells by the systemic or topical administration of a photosensitizer (PS) which should be specifically accumulated and retained on neoplastic areas, followed by the adequate irradiation. In such way it can be foreseen that PDT 


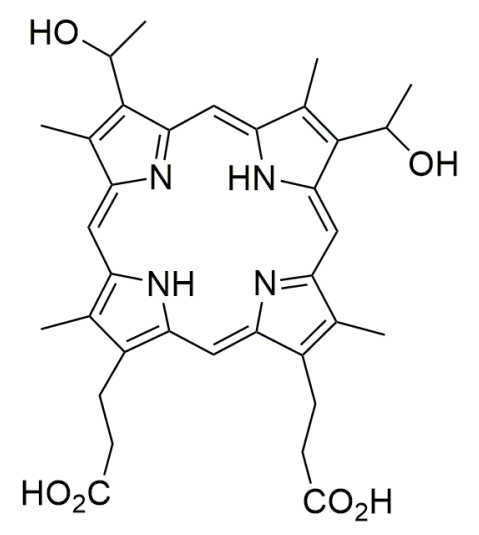

Figure 3 - Hematoporphyrin structure.

will be an easy treatment procedure taking place in any clinic or hospital (Bonnett 2000).

The biological impact for human life of such novel health avenue put scientists from several areas, mainly chemists, biochemists, biologists, physicists and clinicians, working together in order to bring solutions to the life of mankind. A great deal of work started to be performed not only on the establishment of new synthetic methodologies leading to new compounds, mainly porphyrin-type derivatives, as potential new PSs but also on the search of new procedures for their PDT evaluations. The data available in literature at the present time, using key words like e.g. PSs, photodynamic therapy, PS synthesis and medicinal applications, is really impressive.

\section{MECHANISM OF ACTION IN A PDT PROCESS AND REQUIREMENTS OF A PS}

The mechanism taking place in a PDT process has been well discussed. In a simple way it can be stated that the procedure involves the PS topical or intravenous administration and after a known period of time that is followed by visible or near infrared light irradiation at a specific wavelength (Mang 2004). The other partner in the process is the oxygen present in the cancer tissues.

Under the action of the used radiation the PS in its singlet ground state is converted to its excited singlet state; the latter by intersystem crossing gives rise to its long-lived excited triplet state. Such triplet excited species can react with the substrate and with oxygen molecules (in their ground triplet state) present in tissues. Both types of reactions generate reactive oxygen species; in the former case $\mathrm{O}_{2} \doteq \mathrm{H}_{2} \mathrm{O}_{2}, \mathrm{HO}^{\circ}$ species are formed while in the latter case other species like singlet oxygen $\left({ }^{1} \mathrm{O}_{2}\right)$ are formed. Such processes, respectively known as type I and type II reactions, can occur simultaneously; the action of the reactive oxygen species on the cancer cells lead to cellular damage and cancer death (by necrosis or apoptosis). It has been claimed that the type II reaction is the main one taking place in vivo, and thus singlet oxygen is the main reacting species.

It is then clear that any potential PDT PS agent should fulfill certain requirements. One of such compounds should: a) be a single, pure compound obtained in high yield in a few steps well established synthetic methodology; b) be stable with adequate shelf-life and with polar or amphiphilic features for the formulation to be administered or otherwise being possible to have such administration in phospholipid liposomes; c) be a good singlet oxygen generator and also with appreciable fluorescence quantum yield; d) have absorbance at the red / far red region ( $\lambda$ 620-850 $\mathrm{nm})$ where the radiations have deeper penetrations; e) have little or no dark toxicity (Macdonald and Dougherty 2001).

\section{DEVELOPMENT OF PHOTOSENSITIZERS}

As already mentioned, many scientists have considered the PDT field as a new area with great biological significance for life. Since a few decades their research programs have pointed to the several aspects which could really put PDT as a new target methodology against cancer. During decades after the 1960s, reports from several research groups have appeared in the literature 
data about that. Among many scientists who made a great improvement on the search of new PSs based on porphyrin-type derivatives there is one who deserves a special mention. Dougherty using hematoporphyrin derivatives during several years did open the avenue leading to the first clinically approved PS formulation (named Photofrin ${ }^{\mathrm{R}}$ in some countries) (Fig. 4).

Development of PSs along the years was/is carried out always aiming to reach the goal that the new ones could be better than the old ones. The first group, now designated as being the first generation of PSs, are porphyrin macrocycles based on hematoporphyrin and its derivatives (HpD). These really have negative features, since each formulation is a mixture of oligomers which have week absorptions around $630 \mathrm{~nm}$, very low solubility in polar solvents and give rise to prolonged patient photosensitivity (Allison and Sibata 2010). As already mentioned, many scientists have considered the PDT field as a new area with great biological significance for life. Since a few decades their research programs have pointed to the several aspects which could really put PDT as a new methodological target against cancer. During decades after the 1960s, reports from several research groups have appeared in the literature data about that.

Porphyrin-type macrocycles allow structural modifications at the peripheral pyrrolic positions and changes in the synthetic methodologies can lead to new macrocycles. The new compounds can be substituted or expanded porphyrins, chlorins or bacteriochlorins (Fig. 2) or related macrocycles of the corrole (D) and phthalocyanine (E) types (Fig. 5). Ideally such new derivatives would fulfill the PDT requirements in terms of improved physicochemical and therapeutic properties and are included in the group of the PSs' second generation. The development of the third generation of PSs is being considered since a few years ago. It takes into consideration the improvement mainly related with

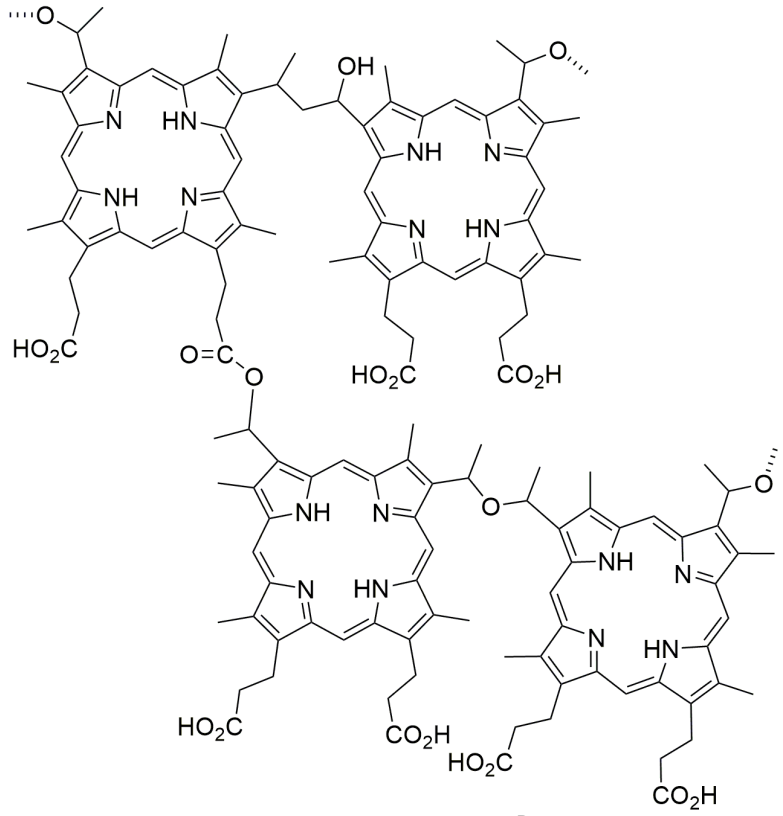

Figure 4 - Generic structure of Photofrin ${ }^{\mathrm{R}}$.

PS transport and specificity for tumors (Josefsen and Boyle 2008, Senge 2012). New or already known PSs are conjugated, for example, with antibodies (Kudarha and Sawant 2017, Hudson et al. 2005, Pereira et al. 2014) or nanoparticles (Yang et al. 2017, Abrahamse et al. 2017, Ma et al. 2017). Targeting strategies have already shown that the PS affinity for tumors increases in significant ways. But this is still an area under development (Moser 1998).

\section{APPROVED PORPHYRIN-TYPE PSS AND OTHERS UNDER CLINICAL TRIALS}

Having said that PSs can be highly significant to human beings by their capacity to fight neoplastic cases under the PDT procedure, it should be considered the situation about the availability of such compounds or their formulations. Some of them are available from competing manufacturing companies and others are still under clinical trials. The most significant ones will then be mentioned (Chilakamarthi and Lingamallu 2017, Abrahamse and Hamblin 2016). 


\section{PHOTOFRIN}

This PS formulation is mainly a mixture of hematoporphyrin oligomers with linkages with $\mathrm{C}-\mathrm{C}$, ether and ester bonds. These were obtained by treating hematoporphyrin with sulfuric acid in acetic acid at room temperature (the so called stage I); the purple solid obtained was a mixture, where hematoporphyrin diacetate was the main component. The solid was taken in aqueous base to reach neutrality for producing a solution for injection. That originated a mixture of monomers (hematoporphyrin, vinylated and other ones from the elimination taking place at the acetoxyethyl groups) accompanied by a mixture of higher molecular weight derivatives (dimers and other oligomers). The latter mixture showed to be more biologically active than the monomers. Separation of monomers from the oligomers by HPLC or gel permeation gave a fraction called hematoporphyrin derivative (HpD stage II). This HpD oligomeric mixture gave rise in 1993 to a PS formulation commercialized under the trade name Photofrin ${ }^{\mathrm{R}}$ by QLT Photo Therapeutics, Vancouver. Photofrin started to be used in several countries (e.g., Canada, USA, UK, France and others). Commercial variants (Photosan, Photogem, Photocarcinorin) are available in other countries. The clinical indications point mainly to oesophagus, cervical, lung and superficial bladder cancers.

The mentioned formulations are still the first generation of PSs. Their clinical use is still going on although they do not fulfil the requirements of an ideal PS. Each formulation is a mixture of oligomers, the absorption band I at around $630 \mathrm{~nm}$ is weak and there is appreciable phototoxicity for skin. This has motivated scientists looking for new generation of PSs.

\section{FOSCAN}

Foscan $^{\mathrm{R}}$ is a brand name of temoporfin, a PS used in the European Union since the year 2001 for head,
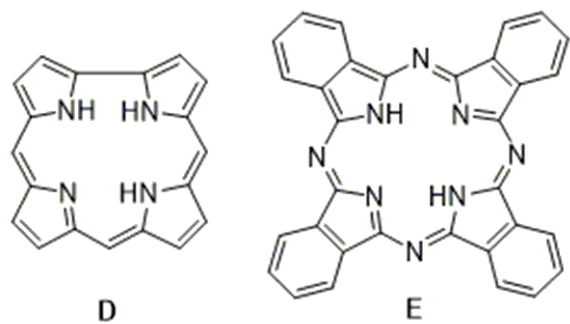

Figure 5 - Corrole (D) and Phthalocyanine (E) macrocycles.

neck, lung and brain cancer types. Studies on its use for other types of cancer are still being carried out. The dosing and irradiation times on its use is significantly smaller than in the Photofrin case. This second generation PS is a chlorin derivative [5,10,15,20-tetrakis ( $m$-hydroxyphenyl)chlorin] (Fig. 6).

The formulation contains a single active compound; being a chlorin derivative it is photoactivated at $652 \mathrm{~nm}$, where it is a very good singlet oxygen generator. Its synthesis was reported by Bonnett and collaborators from the reduction of the corresponding porphyrin with diimide (Bonnett et al. 1989, Horlings et al. 2015).

ALA

5-Aminolevulinic acid is an intermediate in the biosynthetic process leading to protoporhyrin IX and then to heme (Battersby et al. 1980, Shemin and Russell 1953). The conversion rate of that enzymatic conversion is controlled. If ALA is administered in excess there will be the formation of protoporphyrin IX, which accumulates in vivo and can act as a PS. Neoplastic cells produce the porphyrin in much higher amounts than the normal cells in the situation with the excess of ALA. In this way ALA is a pro-drug and can be formulated for topical, oral or intravenous applications. The ALA formulation $\left(\right.$ Levulan $^{\mathrm{R}}$ ) is being used by dermatologists to treat several skin malignances like squameous cell tumors and actinic keratosis (Choudhary et al. 2009, Attia 2013). Head and neck 


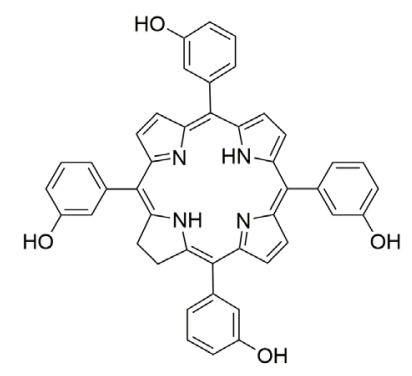

Figure 6 - Temoporfin structure.

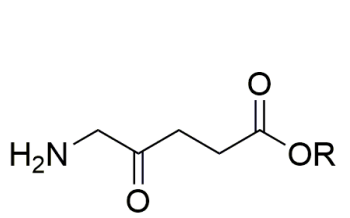

ALA: $\mathrm{R}=\mathrm{H}$

Metvix: $\mathrm{R}=\mathrm{CH}_{3}$

Hexvix: $\mathrm{R}=\mathrm{C}_{6} \mathrm{H}_{13}$

Benzvix: $\mathrm{R}=\mathrm{C}_{6} \mathrm{H}_{5} \mathrm{CH}_{2}$

Figure 7 - Structures of ALA, Metvix, Hexvix and Benzvix.

tumors, Barrett's esophagus, bladder and prostate cancers have also been approached with ALA formulations.

ALA alkyl esters have higher lipophilicity and as a result they demonstrate deeper penetration in the tissues. Esterases acting at the target tissue will perform the dealkylation. ALA methyl (MetvixR), hexyl (Hexvix) and benzyl (Benzvix) esters have demonstrated excellent results in several clinical studies; in particular Hexvix can be used to enhance the detection of bladder cancer and veterinary doctors also use ALA or ALA esters to treat pets' tumors (Fig. 7) (Plaetzer et al. 2009).

ALA and ALA esters are also being considered in the treatment of cases of acne, psoriasis, cutaneous leishmaniasis and other skin malignancies (Keyal et al. 2016, Choi et al. 2015, Sidoroff 2014).

\section{VISUDYNE}

Visudyne $^{R}$ is the brand name of Verteporphin, a chlorin derivative formulated for injection as a mixture of two isomers (Fig. 8).

These can be obtained from the Diels-Alder mono-cycloaddition of protoporphyrin IX dimethyl ester with dimethyl acetylenedicarboxylate
(Morgan et al. 1984). Visudyne can be activated at $690 \mathrm{~nm}$ but PDT studies with it did not demonstrate promising applications in that area; however Visudyne became a clinically approved PS with ophthalmic significance. Visudyne is being used against the age-related macular degeneration; this is a disease which usually appears in people over 50 years of age and if not treated will bring blindness.

MACE

Mono-L-Aspartyl chlorin e6 is a chlorin derivative (H) which is under clinical analysis (Fig. 9). It is also commercialized under other names like NPe6, Apoptsin, Laserphyrin, Talaporfin sodium, LS11 and Litx ${ }^{\mathrm{TM}}$ (Allison and Sibata 2010, Bonnett and Martínez 2001, Gomi et al. 1998). It is being assessed against liver, brain, colon and neck tumors. Its irradiation takes place at $664 \mathrm{~nm}$. It can be obtained from the treatment of chlorin e6 $(\mathbf{G})$ with di-t-butyl aspartic acid and DCC, followed by purification and hydrolysis. The precursor chlorin e6 can be obtained from the oxidation of chlorophyll $a$ (F) (Kadish et al. 2010).

\section{PHOTOCHLOR}

This is a chlorin derivative [3-(1-hexyloxyethyl)-3devinlypyropheophorbide $a$ ] (Pandey et al. 1996) (J) which can be obtained from pyropheophorbide $a$ (I), a product of chlorophyll $a$ degradation (Fig. 10).

It can be excited at $665 \mathrm{~nm}$. It is under clinical evaluation for Barrett's esophagus and endobronchial lung cancers. However there has been success in treating tumors present in dogs and cats.

\section{TOOKAD}

Tookad is the trade name of Padoporfin $(\mathbf{L})$, a Pd (II) bacteriochlorophyll derivative (Fig. 11).

It is a PS which is activated at $763 \mathrm{~nm}$ and has been considered in studies related with the treatment of prostate cancer. However the results obtained pointed to the possibility that such therapy 

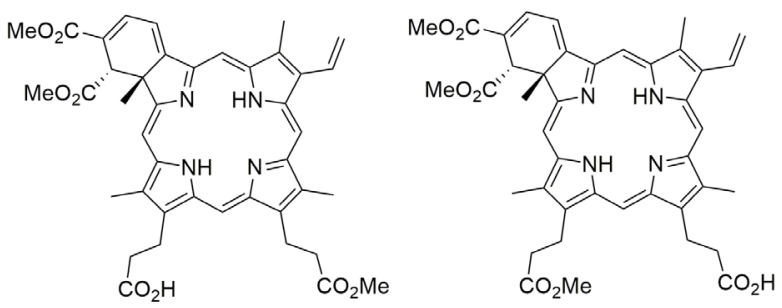

Figure 8 - Structures of Visudyne isomeric mixture.
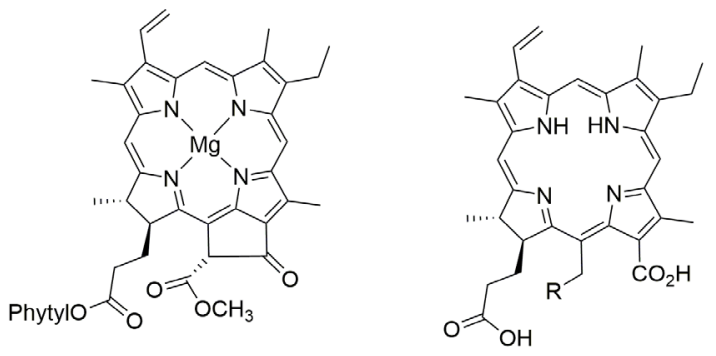

$\mathbf{F}$



Figure 9 - Structures pf chlorophyll $a(\mathbf{F})$, chlorin e6 $(\mathbf{G})$ and $\operatorname{MACE}(\mathbf{H})$.
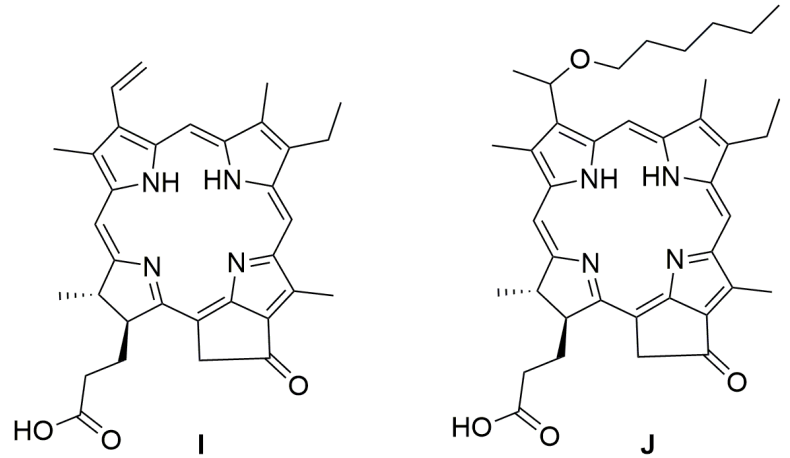

Figure 10 - Structure of pyropheophorbide $a(\mathbf{I})$ and Photochlor (J).



K

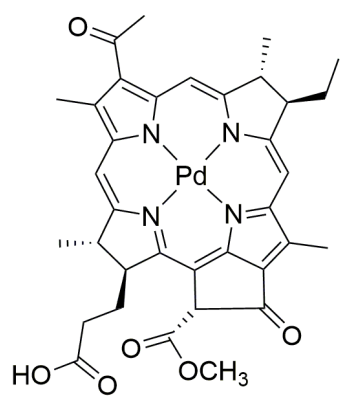

L
Figure 11 - Structures of bacteriochlorophyll $a(\mathbf{K})$ and Tookad (L). could be still premature. In such way a few Tookad derivatives with lipophilic features are being targets in prostate cancer studies (Brandis et al. 2005, Moore et al. 2015, Allison and Sibata 2010, Azzouzi et al. 2015, Scherz and Salomon 2013).

The Tookad synthesis can be performed from bacteriochlorophyll $a(\mathbf{K})$ by acidic hydrolysis followed by $\mathrm{Pd}(\mathrm{II})$ complexation.

The synthesis of other porphyrin derivatives as potential PSs has been carried out by several research groups and has given rise to several scientific publications. In the following part of this review it will be compiled the work on the synthesis and in vivo and in vitro biological evaluations of several potential PDT photosensitizers which were developed at the Aveiro University since 1997.

\section{POTENTIAL PSS DEVELOPED IN AVEIRO AND THEIR BIOLOGICAL EVALUATIONS}

\section{$1^{\text {ST }}$ AND $2^{\text {ND }}$ GENERATION PHOTOSENSITIZERS}

Facing the phototherapeutic efficacy found for certain oligomeric components of Photofrin, namely dimers (Dougherty 1993) and also of amide-substituted porphyrins (Woodburn et al. 1992, Boyle and Dolphin 1996) the Aveiro group started a program in 1997 concerned with the synthesis and biological evaluation of dimers Dim 1-4 linked with an amide bond (Fig. 12) (Faustino et al. 1997, 2000).

The porphyrin-porphyrin dimers Dim 1, Dim $\mathbf{2}$ and Dim 3 and the porphyrin-chlorin dimer Dim 4 were synthesized by coupling the acid chloride of porphyrin 5 with the adequate amino-substituted compounds 6a-c (Fig. 13). These amino derivatives were obtained by reduction of the adequate nitroporphyrins with sodium borohydride. The chlorin 7 was prepared by reducing one of the pyrrolic units of the amino derivative $\mathbf{6 c}(\mathrm{R}=$ 3-OMe) with $p$-toluenesulfonylhydrazine. The key compounds for the synthesis of the monomeric units or of their precursors were obtained by following 
the cross Rothemund approach using pyrrole and the appropriate benzaldehydes at reflux in acetic acid and nitrobenzene.

In these pioneer studies the pharmacokinetic behavior of all dimers were examined in vivo using Balb/c mice bearing MS-2 fibrosarcomas. The treatments were performed by intravenous injection after incorporation of the dimers into DL$\alpha$-dipalmitoylphosphatidylcholine liposomes. In all cases the maximal efficiency and selectivity of PS accumulation in each tumor tissue took place at $24 \mathrm{~h}$ after drug administration and also an almost complete clearance of the dimers from the serum and skin were detected after 1 week. Compounds Dim 2 and Dim 3 showed a higher selectivity for tumor localization (tumor/peritumoral tissue dye concentration ratios respectively of 62 and 136 at $24 \mathrm{~h}$ after drug administration) when compared with Dim 1 (tumor/peritumoral ratio $=20$ ), suggesting that the presence of the methoxy substituents in the meso-phenyl groups is a particularly favorable feature. Additionally the decreased amount of dimer Dim 4 bearing the chlorin unit in the intramuscular MS-2 fibrosarcoma and an appreciably larger uptake in the muscle (tumor/peritumoral ratio = 4) seemed to indicate that the reduction of one of the pyrrolic units had a negative influence on the affinity of this class of porphyrin derivatives for neoplastic tissues. The phototherapeutic efficiency of dimer Dim 3 was evaluated by following the growth curves of fibrosarcoma irradiated with red light $(600-700 \mathrm{~nm})$ with a total dose of $400 \mathrm{~J} \mathrm{~cm}^{-2}$, at $24 \mathrm{~h}$ after intravenous injection; a significant delay was observed in the tumor growth when compared to the one of the untreated control mice.

Having in mind the potential use of porphyrins in photodiagnosis and the medical applications of ${ }^{19} \mathrm{~F}$ NMR spectroscopy, the synthetic access and the biological evaluation of chalcone-porphyrin conjugates chalc-por 8, 10 and $\mathbf{1 1}$ were reported (Figures 14 and 15) (Serra et al. 2009). For both strategies it was selected the easily accessible

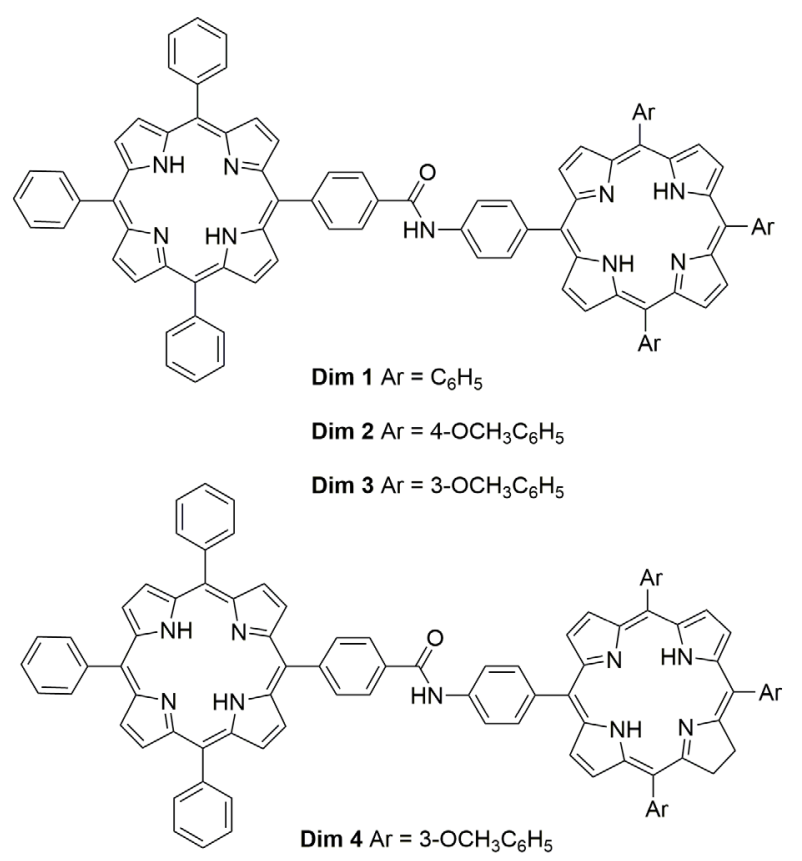

Figure 12 - Structures of dimers Dim 1-4 linked by amide bonds.

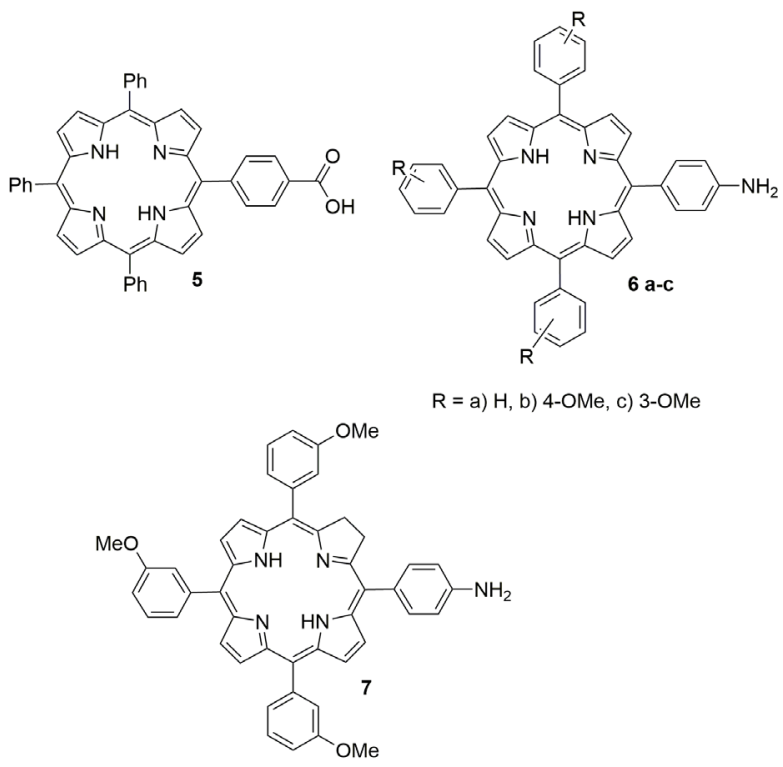

Figure 13 - Structures of precursors used to prepare dimers Dim 1-4.

chalcone 9, with only one free hydroxyl group to be conjugated to porphyrins $\boldsymbol{m}-\mathbf{C H}_{3} \mathbf{O T P P}$ [5,10,15,20-tetrakis(3-methoxyphenyl)porphyrin] and $\mathbf{T P P F}_{20}[5,10,15,20$-tetrakis(pentafluoroph enyl)porphyrin]. The chalc-por 8 was obtained in excellent yield $(97 \%)$ from the reaction of 
the activated ester $\mathbf{1 2}$ with chalcone $\mathbf{9}$ in DMSO in the presence of potassium carbonate, at room temperature (Fig. 14). The other two chalc-por 10 and 11 were obtained from the reaction of porphyrin $\mathbf{T P P F}_{20}$ with chalcone $\mathbf{9}$, in DMSO in the presence of $\mathrm{Na}_{2} \mathrm{CO}_{3}$ (Fig. 15). The nucleophilic substitution of only one para fluorine atom or of the four para fluorine atoms were controlled by playing with the amount of porphyrin $\mathbf{T P P F}_{20}$ and chalcone $\mathbf{9}$ and by a careful selection of the temperature.

The biological evaluation was performed in vitro in COS-7 cells and all the conjugates showed to be highly photostable under light irradiation giving good cellular fluorescence images. It was found that the compounds localized mainly near the nuclear area upon internalization and the tetra-substituted chalc-por $\mathbf{1 1}$ showed a higher uptake than the mono-substituted chalc-por 10, reflecting an advantageous replacement of the para fluorine atoms by chalcone moieties. Contrary to the chalcone free porphyrin $\boldsymbol{m}-\mathbf{C H}_{3}$ OTPP that induced COS-7 cell toxicity in a concentration- dependent manner, all the chalcone-porphyrinic derivatives showed similar non cytotoxic and non photocytotoxic profiles. So it was concluded that the chalcone moiety induces a protective effect concerning the cytotoxic characteristics of the precursor porphyrin $\boldsymbol{m}-\mathbf{C H}_{3}$ OTPP. Based on these features, it was commented that these chalconeporphyrin conjugates could be considered as agents for cancer diagnosis and the fluorinated derivatives also for cancer diagnosis using ${ }^{19} \mathrm{~F}$ NMR imaging.

Photodynamic therapy (PDT) is being considered as an efficient alternative to treat basal and squamous cell carcinoma or precancerous states such as solar keratoses. In order to overcome the problems associated with the preparation of formulations containing hydrophobic PSs required for the systemic or topic administration, the photodynamic activity of the tri-cationic 5-(4-carboxyphenyl)-10,15,20-tris(4methylpyridinium-4-yl)porphyrin tri-iodide 13 and of its conjugate poly-S-lysine $\mathbf{1 4}$ were evaluated in NCTC 2544 human keratinocytes (Fig. 16) (Silva et al. 2006). Previous studies showed that the



i. a) $\mathrm{SOCl}_{2}$ dry py, $30 \mathrm{~min}$; b) $\mathrm{N}$-hydroxysuccinimide, $3 \mathrm{~h}, 50^{\circ} \mathrm{C}$; ii. $\mathrm{K}_{2} \mathrm{CO}_{3}, \mathrm{DMSO}, 1.5 \mathrm{~h}$

Figure 14 - Synthesis of chalcone-porphyrin derivative 8. 


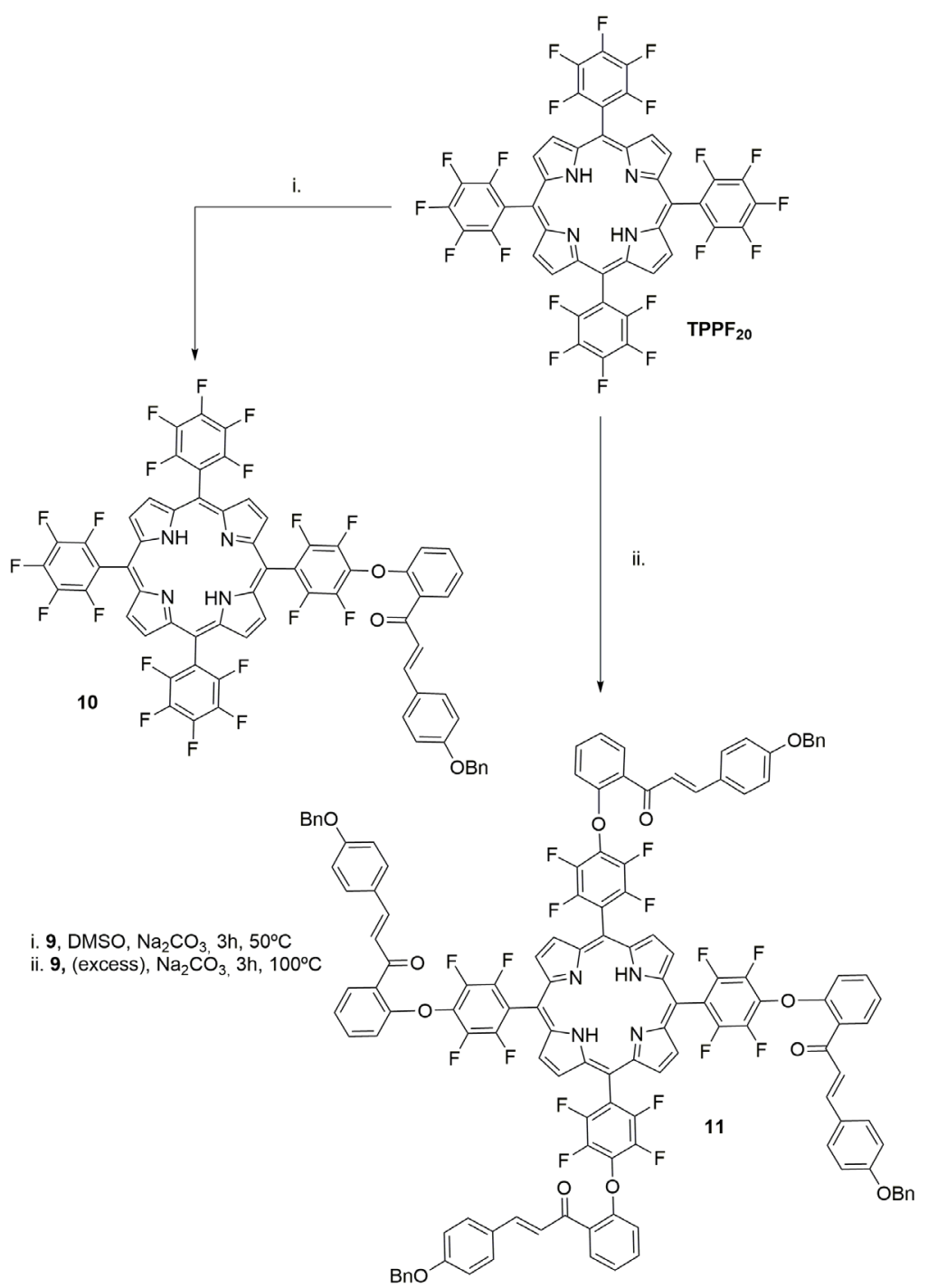

Figure 15 - Synthesis of chalcone-porphyrin derivatives 10 and 11.

conjugation of this polypeptide side-chain to the tricationic meso-tetrasubstituted porphyrin $\mathbf{1 3}$ had a positive impact in the photoinactivation of both Gram-(+) and Gram-(-) bacteria (Tome et al. 2004, Soncin et al. 2004, Gad et al. 2004).

The biologicalstudies with derivatives 13 and 14 showed that PS 14 has the highest photocytotoxicity when compared with its precursor 13; this behavior was probably related with its highest uptake and with the intracellular localization and not with its photodynamic effectiveness. With both PSs little or no staining of the nucleus was observed.
As an extension of the previous studies the photocytotoxicity of other tricationic porphyrin conjugates 15a-d (Fig. 17) bearing (a) methyl, (b) $N, N^{\prime}$-dicyclohexylureidooxycarbonyl, (c) di-Oisopropylidene-(-D-galactopyranosyl) or (d) $\alpha / \beta$ D-galactopyranosyl chains was also evaluated and compared with the tricationic acid precursor $\mathbf{1 3}$ (Silva et al. 2010).

The studies have shown that the conjugate chains were efficiently taken up by proliferating NCTC 2544 keratinocytes and derivatives 15a, 15b and 15c exhibit a much larger photocytotoxicity than derivatives $\mathbf{1 3}$ or $\mathbf{1 5 d}$ at an 

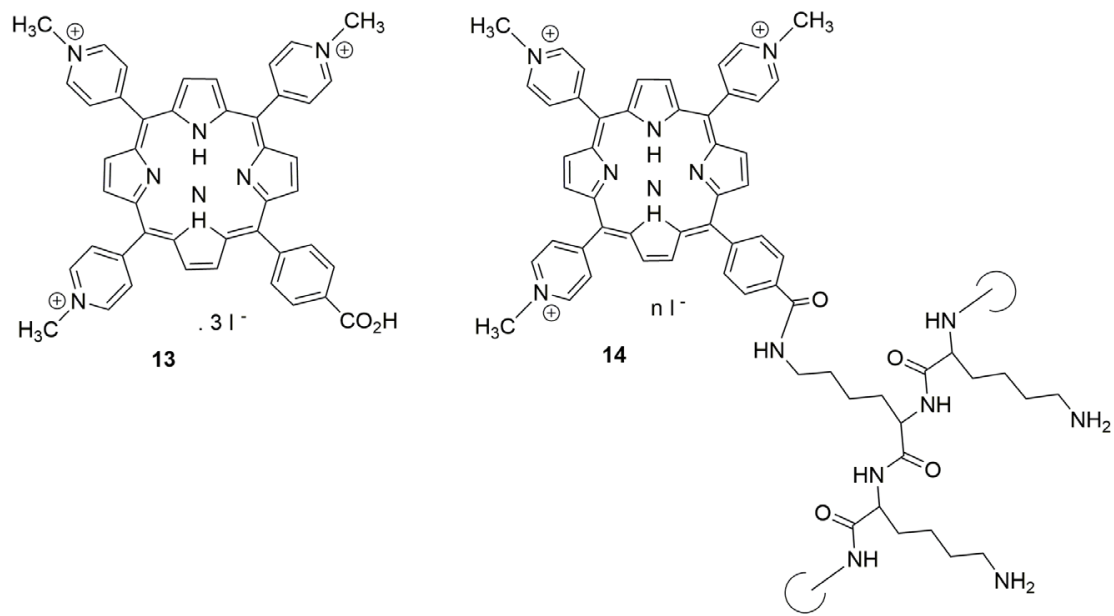

Figure 16 - Chemical structures of the poly-S-lysine conjugate 14 and of its tricationic acid precursor 13.

incubation concentration of $5 \mu \mathrm{M}$. In fact, lower concentrations of $\mathbf{1 5 a}, \mathbf{1 5 b}$ and $\mathbf{1 5 c}$ are sufficient to achieve high photocytotoxicity. The intracellular phototoxic concentration $\left(\mathrm{IPC}_{50}\right)$, which represents the intracellular concentration which produces a $50 \%$ decrease in neutral red uptake after a $30 \mathrm{~min}$ irradiation was also evaluated. Low $\mathrm{IPC}_{50}$ values of $\approx 50$ pmol per $\mathrm{mg}$ of protein were obtained with derivatives 15a $\left(\mathrm{IPC}_{50} \approx 55 \mathrm{pmol} / \mathrm{mg}\right.$ protein), 15b $\left(\mathrm{IPC}_{50} \approx 55 \mathrm{pmol} / \mathrm{mg}\right.$ protein $)$ or $15 \mathrm{c}\left(\mathrm{IPC}_{50} \approx 50\right.$ $\mathrm{pmol} / \mathrm{mg}$ protein) with a relative efficiency of $\mathbf{1 5 c}>$ $\mathbf{P 1 5} \mathbf{b}=15 \mathbf{a}>>15 \mathbf{d}\left(\mathrm{IPC}_{50}>50 \mathrm{pmol} / \mathrm{mg}\right.$ protein $)>$ $13\left(\mathrm{IPC}_{50} \gg>35 \mathrm{pmol} / \mathrm{mg}\right.$ protein). It was remarked that the photocytotoxic potential of $15 \mathbf{a}, \mathbf{1 5} \mathbf{b}$ and $\mathbf{1 5 c}$ is similar to that of endogenous protoporphyrin IX induced by the pro-drugs currently used for PDT of skin lesions, the $\delta$-aminolevulinic acid or its esters. The microfluorometry results allowed to conclude that $\mathbf{1 5 a}, \mathbf{1 5 b}$, and $\mathbf{1 5} \mathbf{c}$ are localized in endocytotic or pinocytotic vesicles but not in mitochondria or nuclei. The determination of the molecular mechanisms acting in the cell death due to 15c suggested the most significant contributions are related with necrosis and autophagy events and not with apoptosis (Silva et al. 2010).

Knowing that the major limitation of topical PDT is the poor penetration of PSs through
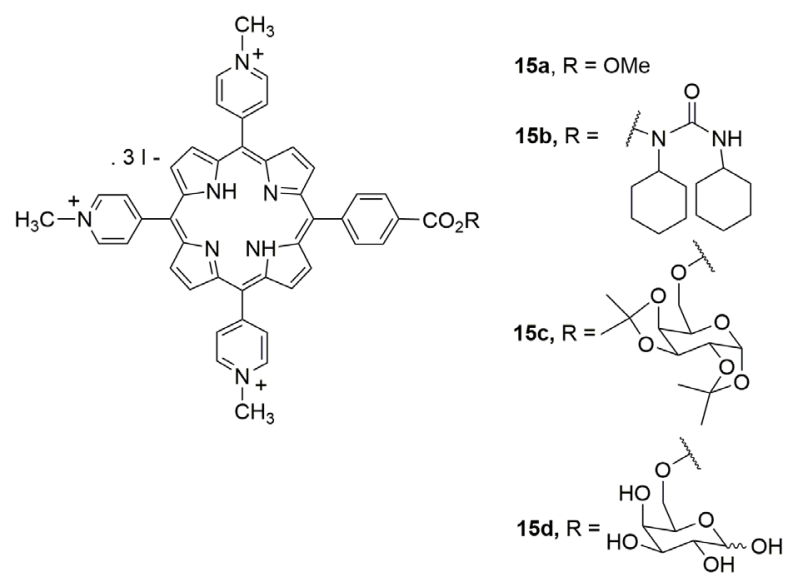

Figure 17 - Structures of tricationic porphyrin conjugates $\mathbf{1 5 a}$ d.

biological barriers, like in normal skin, the penetration efficacy of nanoparticles of lyotropic liquid crystals loaded with chlorin derivatives 16a and 16b (Fig. 18) was evaluated in vitro and in vivo (Petrilli et al. 2013, de Oliveira et al. 2008). The synthetic strategy to obtain the natural-type chlorins was based on the reactivity of the substituent double bonds of protoporphyrin IX dimethyl ester as diene in Diels-Alder reaction (Calvete 2009, Abrahamse and Hamblin 2016, Cerqueira et al. 2017). The cycloaddition reaction was performed between protoporphyrin IX dimethyl ester and maleic anhydride affording the chlorin intermediates $\mathbf{1 7}$ 
(Fig. 18). Then, the regioselective ring-opening in the presence of methanol afforded the amphiphilic chlorins 16a,b.

The nanoparticles of lyotropic liquid crystals (prepared from monoolein, oleic acid and the copolymer poloxamer 407) loaded with the chlorin derivatives $\mathbf{1 6 a}, \mathbf{b}$ showed particles' size of $161 \pm 4 \mathrm{~nm}$. Cell viability studies revealed that the nanodispersion is not harmful for L929 mice fibroblasts and the formulation did not harm the integrity of the skin cells. The in vitro (using skin from excised porcine ears) and in vivo (using hairless mice) penetration studies confirmed that the nanodispersions enabled a higher drug skin uptake when compared with the used control formulation (chlorins 16a,b in polyethylene glycol) with retention rates in the skin equal to $2.72 \pm$ $0.21 \%$ of applied dose $/ \mathrm{cm}^{2}(\mathrm{p}<0.05)$. The obtained results suggested that this type of nanodispersion has efficacy to deliver PSs into the skin, a crucial feature for topical PDT.

Still related with the high efficiency of cationic porphyrin derivatives like 5,10,15,20-tetrakis(1- methylpyridinium-4yl)porphyrin (18) against tumor cells and also bacterial strains (Alves et al. 2009, Oliveira et al. 2009), the therapeutic efficiency of the tricationic porphyrin derivatives 19, 20a, 20b and 21 (Fig. 19) was evaluated. A comparison was also made with the results obtained with the well-known tetracationic porphyrin $\mathbf{1 8}$ (McCormick et al. 2014). The phototoxic action of these derivatives was assessed in human colon adenocarcinoma cells by cell viability, intracellular localization and nuclear morphology analysis; the results showed that porphyrins $19\left(\mathrm{Ar}=\mathrm{C}_{6} \mathrm{H}_{5}\right)$, 20 b $\left(\mathrm{Ar}=4-\mathrm{MeO}_{2} \mathrm{CC}_{6} \mathrm{H}_{4}\right)$ and $21\left(\mathrm{Ar}=\mathrm{C}_{6} \mathrm{~F}_{5}\right)$, caused a more significant decline of cell viability (80-90\% of cell destruction) when compared with the tetracationic derivative $\mathbf{1 8}$ and with 20a $\left(\mathrm{Ar}=4-\mathrm{HO}_{2} \mathrm{CC}_{6} \mathrm{H}_{4}\right)$. It was commented that the extent of cell photodamage is more related with the hydrophobic degree given by the peripheral substituent than with the ability to generate singlet oxygen. The porphyrins were clearly localized as a punctuated pattern in the cytoplasm of the cells,
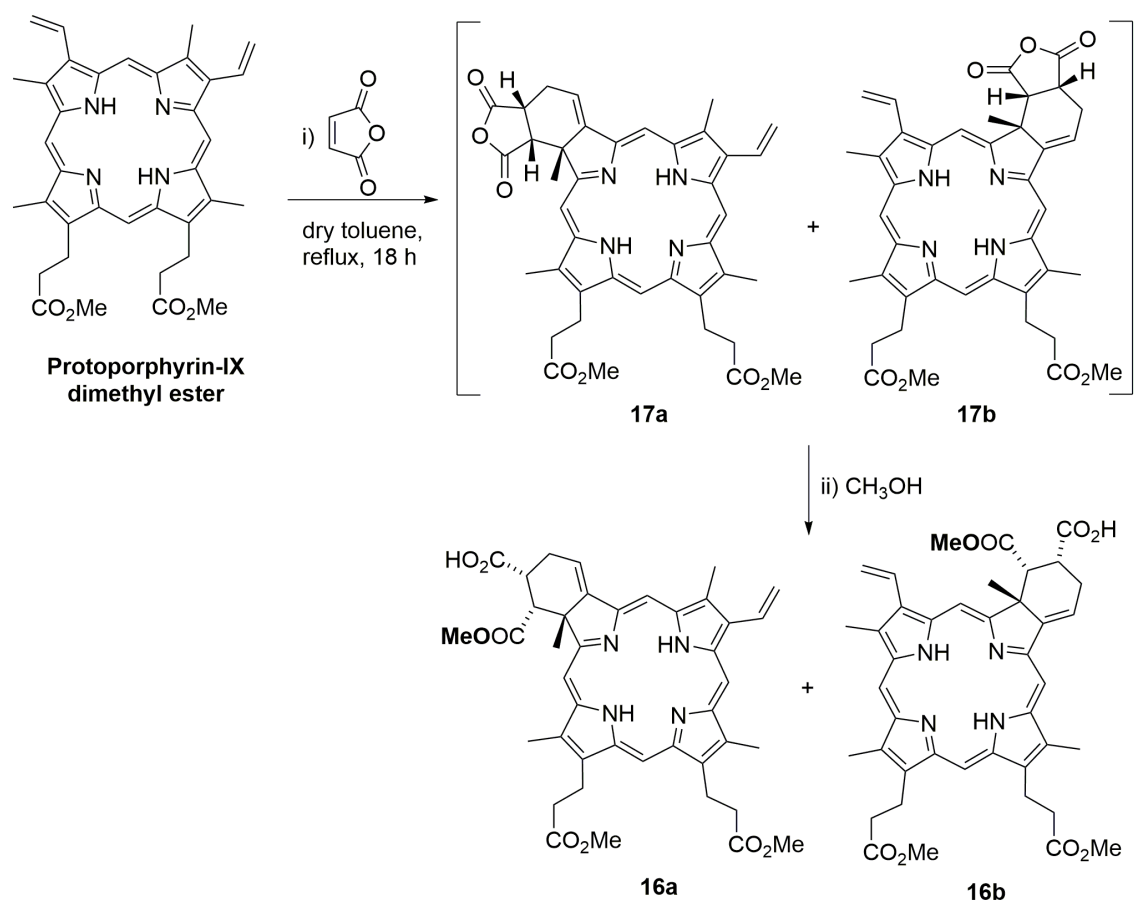

Figure 18 - Synthetic strategy to amphiphilic chlorin derivatives 16a,b. 
and the PDT treatment resulted in apoptotic cell death (McCormick et al. 2014).

\section{$3^{\text {RD }}$ GENERATION PHOTOSENSITIZERS}

The $3^{\text {rd }}$ generation PSs came to overcome the drawbacks of the $1^{\text {st }}$ and $2^{\text {nd }}$ PSs generation (Josefsen and Boyle 2008, Wöhrle et al. 1998). These PSs were created from targeting strategies in order to increase the affinity of the PS for the tumor tissue (Josefsen and Boyle 2008). Thus, these molecules should have properties providing the selective delivery of the PS to the tumor tissue, as for example, through conjugation to biomolecules or by the association of these PS molecules with drug delivery systems (Josefsen and Boyle 2008, Wöhrle et al. 1998, Senge 2012). In fact, there are several reports of selectively targeting subcellular compartments, including the mitochondria (Morgan and Oseroff 2001, Hilf 2007, Aniogo et al. 2017, Battogtokh and Ko 2017).

The targeting strategy to increase the affinity of the PSs for tumors was also used by Cavaleiro' s group. In 2010, new porphyrin amino acid conjugates 22a-d were efficiently prepared by the condensation of several amino acids (glycine, serine, tyrosine and methionine residues) with a porphyrin 23 in the presence of $\mathrm{K}_{2} \mathrm{CO}_{3}$ (Fig. 20) (Serra et al. 2010). All compounds showed high photostability and were able to generate singlet oxygen. It is known that porphyrins coupled with amino acids have been reported to have interesting characteristics for PDT since they have good solubility in aqueous solutions (Raphael et al. 2006); also they can intercalate DNA sequences with high specificity (Biron and Voyer 2005) and have high cellular uptake in tumors (Sutton et al. 2002). With that in mind, the photodynamic effect of liposome formulations of porphyrin amino acid conjugates 22a-d was evaluated on tumoral (HeLa) and on non tumoral (HaCaT) human cell lines. This in vitro study have shown that the liposome formulations of these PSs were able to penetrate efficiently in the cytoplasm of cultured cancer and normal cells and no dark cytotoxicity was observed at the same concentration used for PDT cell treatment and during long incubation time ( $24 \mathrm{~h})$. After the PDT treatment with visible light, the tested compounds showed higher photocytotoxicity in tumoral $\mathrm{HeLa}$ cells than in non tumoral HaCaT cells, confirming the high potential of these amino acid porphyrin conjugates as PSs for PDT (Serra et al. 2010). For example, a high $\mathrm{HaCaT}$ cell survival percentage of $82.69 \pm 0.01 \%$ and $76.87 \pm 5.58 \%$ can be reached with compounds 22a and $\mathbf{2 2 d}$ at concentrations of $2.510^{-7}$ and $3.010^{-7} \mathrm{M}$, respectively, after $5 \mathrm{~min}$ of irradiation. Furthermore, no photocytotoxicity on $\mathrm{HaCaT}$ cells is observed with compound $\mathbf{2 2 d}$ at $6.110^{-7} \mathrm{M}$ and after $20 \mathrm{~min}$ of irradiation with red light. It is interesting to note that compounds $\mathbf{2 2 c}$ and $22 \mathrm{~d}$ at concentrations of $2.5 \times 10^{-7}$ and $1.2 \times 10^{-6}$ $\mathrm{M}$, respectively, show significant phototoxicity in HeLa cells upon $5 \mathrm{~min}$ of irradiation; only surviving cells fractions of $3.74 \pm 3.40 \%$ (compound 22a) and $8.00 \pm 3.90 \%$ (compound $\mathbf{2 2 b}$ ) are observed. A less pronounced phototoxic effect $(56.87 \pm 3.81)$ is detected for compound 6 at $3.0 \times 10^{-7} \mathrm{M}$ and after 5 min.

Using a similar synthetic approach, novel porphyrin conjugates with serum albumins PS Alb (BSA and HAS proteins) and monoclonal antibodies PS mAb (anti-CD104 and anti-Caf) were prepared (Fig. 21) (Pereira et al. 2014a). In fact, porphyrins and their derivatives conjugated with human and bovine serum albumin (HSA and BSA, respectively) have been successfully prepared and have demonstrated remarkable cell type specificity towards tumoral macrophage-like cells when compared to cancer cells (Hamblin and Newman 1994, Sutton et al. 2002, Hudson et al. 2005, Pereira et al. 2015). This fact, was justified by the high accumulation of albumin in tumor tissues due to the EPR effect (enhanced permeability and retention of macromolecules in 



Figure 19 - Structures of cationic porphyrin derivatives $\mathbf{1 8}$, 19, 20a,b and 21.

tumor tissues) (Kratz 2008, Maeda et al. 2000). Such EPR feature is the result of two effects: firstly, blood vessels of tumor tissues have an enhanced vascular permeability for circulating albumin and, secondly, it was demonstrated that macromolecules having a molecular weight higher than $40 \mathrm{kDa}$ have a reduced clearance from the tumor tissue (Kratz 2008, Maeda et al. 2000). On the other hand, the conjugation of PSs with target-specific antibodies allows the efficient delivery of the PS to the target cell type (Hudson et al. 2005, Bullous et al. 2011). Monoclonal antibodies (mAbs) are attractive due to their features as markers with clinical success, since several therapeutic mAbs have been already approved by the US Food and Drug Administration (Waldmann 2003). In particular, mAb anti-CD104 recognizes the human antigen $\mathrm{CD} 104$, which has a key role in tumorgenicity; its overexpression in colorectal and bladder carcinomas has been reported (Falcioni et al. 1988, Simon-Assmann et al. 1994).

The photodynamic effect studies in human bladder cancer cell line UM-UC-3 have shown that porphyrin conjugated with an anti-CD104 mAb derivative (PS mAb-anti-CD104) showed higher efficiency against that cancer cell line with lower concentrations when compared with the results obtained with porphyrin conjugated with HSA or

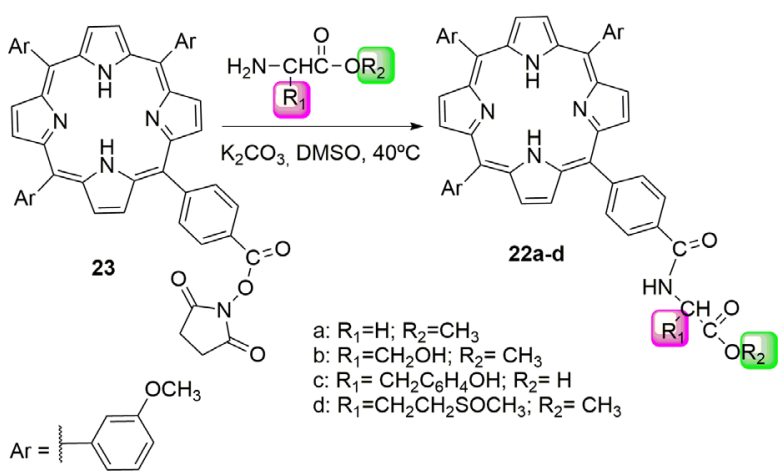

Figure 20 - Synthetic strategy to porphyrin amino acid conjugates 22a-d.

BSA derivatives (PS Alb-HAS and PS Alb-BSA) (Fig. 22) (Pereira et al. 2014a). The antibody's immunoreactivity was unaffected and the ability of this PS to generate phototoxicity mediated by ROS production was improved. These results demonstrated the high potential of albumin and $\mathrm{mAb}$ anti-CD104 as vehicles for targeted delivery of porphyrin to bladder cancer cells (Pereira et al. 2014a).

One of the major challenges in the use of porphyrins and its derivatives in PDT is the delivery of a hydrophobic drug. These compounds have low solubility in aqueous media, which difficult their biodistribution (Zhou et al. 2016). So, it's factual that the development of drug delivery strategies that can carry these PSs to cancer cells is a research area of enormous importance. In fact, the development of PS drug delivery systems based on nanotechnology is an emerging approach to PDT. Liposomes, cyclodextrins (CDs) dendrimers, polymeric and metallic nanoparticles, porphyssomes, quantum dots and carbon nanotubes are examples of formulations that can be used as multifunctional platforms for in cancer photodynamic therapy (Bae et al. 2014, Zhou et al. 2016). CD is a macrocyclic oligo sugar with wide commercial availability and easy modification. It can interact with many guests with suitable sizes and are considered as good 




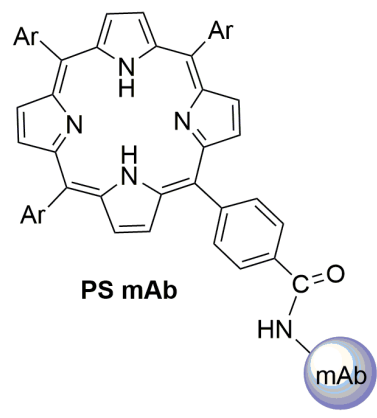<smiles>[Te]=Ic1ccncc1</smiles>

Figure 21 - Synthetic approach to porphyrin conjugates with serum albumins PS Alb (BSA and HAS proteins) and monoclonal antibodies PS $\mathrm{mAb}$ (anti-CD104 and anti-Caf).


Figure 22 - Phototoxicity Ps Alb conjugates and PS mAb - anti-CD104 immunoconjugate in UM-UC-3 cells. This cell line was incubated in the dark with the compounds at different concentrations or with PBS (control) for $4 \mathrm{~h}$ and irradiated for $40 \mathrm{~min}$. The cell survival fractions were determined $24 \mathrm{~h}$ after treatment by the MTT colorimetric assay. There is no significant reduction of MTT in UM-UC-3 cells treated with non-conjugated Por 1 -PDT $(\mathrm{p}<0.05)$ in relation to the control. There are significant differences in the MTT reduction of Por 1-albumins/-mAb anti-CD104 when compared with the control. The MTT reduction produced by Por $1-\mathrm{BSA}$ at $1 \mu \mathrm{M}$ is statistically different when compared with the one for Por 1-HSA. **Significantly different from Por $1-\mathrm{BSA}$ at $0 \mu \mathrm{M}(\mathrm{p}<0.05),{ }^{\$ S}$ Significantly different from Por $1-\mathrm{HSA}$ at $0 \mu \mathrm{M}(\mathrm{p}<0.05)$, ${ }^{\#}$ significantly different from Por $1-\mathrm{HSA}$ at the same concentration. ${ }^{++}$Significantly different from Por $1-\mathrm{mAb}$ anti-CD104 at $0 \mu \mathrm{M}(\mathrm{p}<0.05)$. The values are presented as mean \pm standard deviation of 3 independent experiments $(n=3)$, using the control as a reference value for cellular viability (100\%). Reproduced from Pereira et al. 2014a with permission of The Royal Society of Chemistry. 
choices for the applications in drug delivery systems due to their adjustable water solubility, good biocompatibility, and nontoxicity toward biological systems. Moreover, CDs can reduce the toxicity of the drug molecules and of the grafted polymers and to bring additional benefits such as membrane absorption enhancement, molecular stabilization, and improvement of water solubility as well as the availability of drugs in biological systems (Peng et al. 2017). Actually, the conjugation of PSs with these non-toxic molecules showed improvement on their amphiphilicity, biocompatibility and availability at the surface of cancer cell membranes (Mazzaglia et al. 2003, Sortino et al. 2006).

Phthalocyanines are a group of synthetic macrocycles with structural relationship with porphyrins and with promising photophysical features to be considered as PS for PDT (a highly intense absorption band in the near infrared leading to efficient singlet oxygen generation). Having this in mind and in order to overcome the aggregation usually associated to these highly hydrophobic molecules, Lourenco et al. reported in 2014 the synthesis of amphiphilic phatalocyanines (PCs) conjugated with $\alpha-, \beta$ and $\gamma$ - cyclodextrins as potential PSs for PDT (Lourenço et al. 2014). Thus, Pc- $\alpha-C D$ 24, Pc$\beta-C D 25$ and Pc- $\gamma$-CD 26 were synthesized by nucleophilic substitution of two fluorine atoms of $\mathbf{P c F}_{16}$ (hexadecafluorophthalocyanine), a single substitution of a $\beta$-fluoro atom in one of the isoindole units followed by a second attack in another one of the adjacent isoindole unit, using, respectively, cyclo-maltohexaose $(\alpha-C D)$, cyclomaltoheptaose $(\beta-\mathrm{CD})$ and cyclo-maltooctaose $(\gamma$ CD) (Fig. 23) (Lourenço et al. 2014).

The Pc- $\alpha-C D 24$ and Pc- $\gamma-C D 26$ derivatives exhibited higher water solubility, ${ }^{1} \mathrm{O}_{2}$ production and intracellular ROS generation in UM-UC-3 bladder cancer cell line than Pc- $\beta-C D 25$. The photodynamic effect studies revealed also that the $\alpha$ - and $\gamma$-derivatives were more effective against
UM-UC-3 bladder cancer cells line, producing higher phototoxicity than the Pc- $\beta-C D 25$ analogue. These results were sustained by the intracellular localization study that revealed that Pc- $\beta-C D 25$ is poorly taken up by the cells, while Pc- $\alpha-C D 24$ and Pc- $\gamma$-CD 26 derivatives are accumulated inside the cells to a much higher extent (Fig. 24). All these results suggest that the higher phototoxicity of these compounds can be attributed to their higher cellular uptake and efficiency in generating intracellular ROS (Lourenço et al. 2014).

Corroles are also a group of tetrapyrrolic derivatives strongly related with porphyrins which are also playing a special role in PDT medicinal applications (Barata et al. 2017). In such way, the strategy of conjugation of a CD to a corrole derivative in order to increase the PS solubility, contributing to an efficient delivery of the drug to the tumoral cell, was also reported by the same research group. In this work, new corrole $\beta$-cyclodextrin conjugates Corr- $\beta$-CD 27 (one unit of $C D$ ) and Corr- $\beta$-CD 28 (two units of $C D$ ) were prepared from 5,10,15-tris(pentafluorophenyl) corrole (TPFC) based on the substitution of the para fluorine atoms of this tetrapyrrolic macrocycle (Fig. 25) (Barata et al. 2015).

The prepared corrole $\beta$-cyclodextrin conjugates have shown high photostability and capacity to generate ${ }^{1} \mathrm{O}_{2}$ and to be photocytotoxic towards HeLa cancer cell line. In fact, the cell survival after the PDT treatment with visible light was dependent on the light exposure level and compound concentration. Corr- $\beta$-CD 27 derivative was able to penetrate efficiently in the cytoplasm of the HeLa cells and by fluorescence microscopy it was possible to see that this compound as well as the starting corrole TPFC accumulate in the lysosomes and in the Golgi complexes of HeLa cells, respectively. In fact, TPFC and Corr- $\beta-C D$ 27 caused photocytotoxicity in tumoral HeLa cells and induced a rapid metaphase blockage of cells that also showed clearly altered configurations 


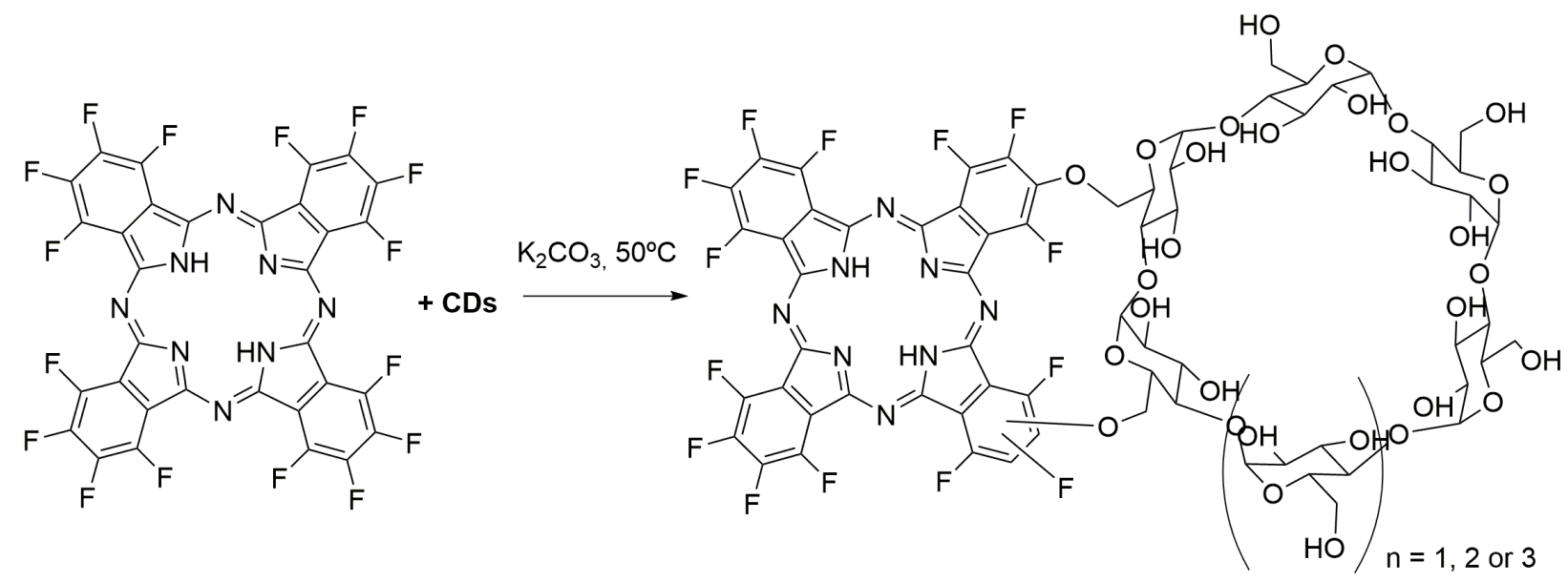

$\mathrm{PCF}_{16}$

24. $\operatorname{Pc}-\alpha-C D(n=1) ; 25 . P c-\beta-C D(n=2) ; 26 . P C-\gamma-C D(n=3)$

Figure 23 - Synthesis of amphiphilic phthalocyanines (PCs) conjugated with $\alpha$-, $\beta$ - and $\gamma$ - cyclodextrins.
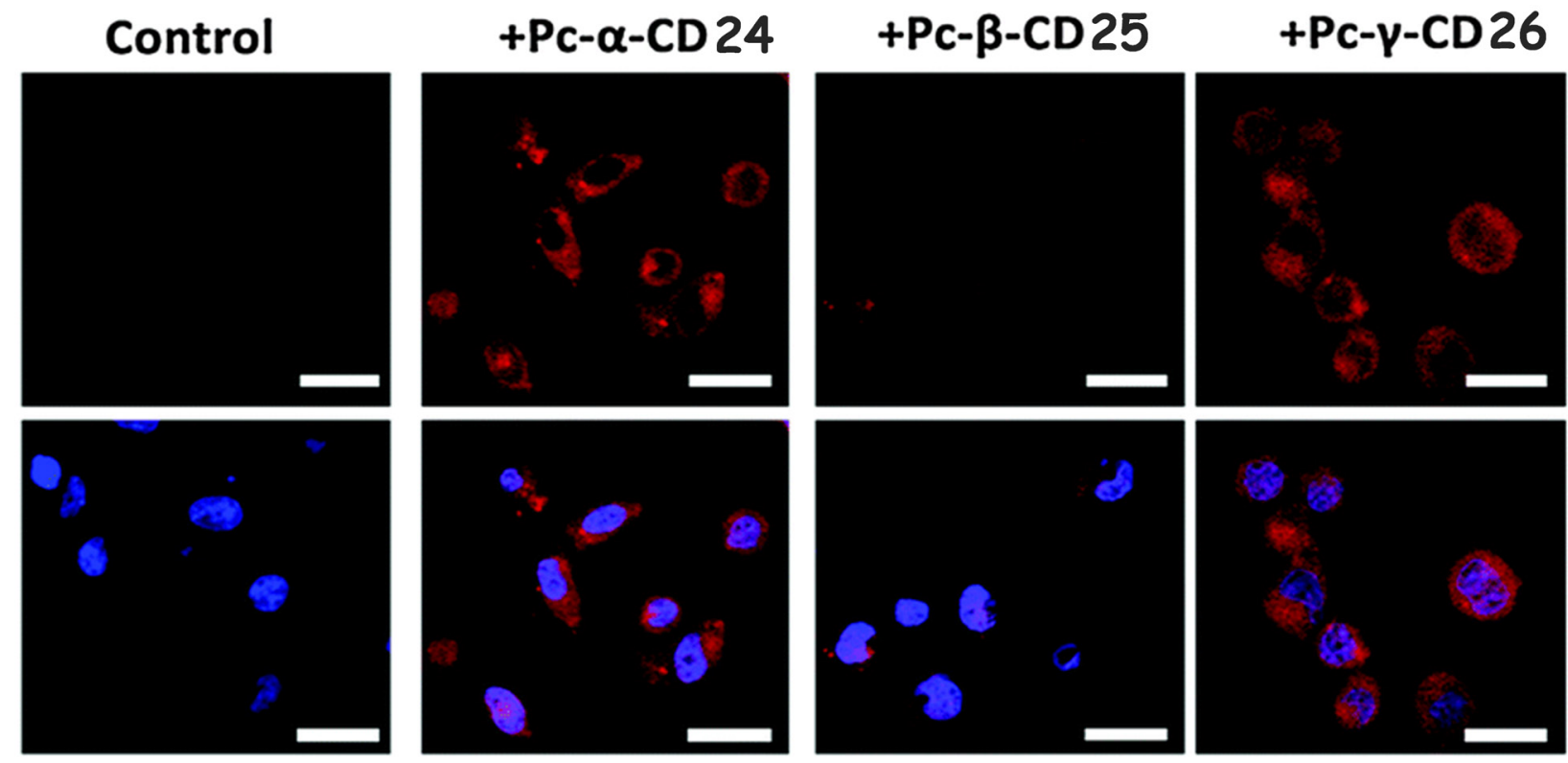

Figure 24 - Representative fluorescence images of UM-UC-3 bladder cancer cells incubated with Pc-CDs 4-6 (red) in darkness and the cell nucleus stained with DAPI (blue). Scale bars $20 \mathrm{~mm}$. Reproduced from Lourenco et al. 2014 with permission of The Royal Society of Chemistry.

of the mitotic spindle. Surprisingly, the MTT cytotoxicity studies indicated that TPFC had the highest efficacy at the lower concentration, with a decrease in the cell viability of $38.5 \pm 1.4$ after a total light dose of $12 \mathrm{~J} / \mathrm{cm}^{2}$. This PS also affects the mitotic spindle. These facts, associated with the easy access to these corrole conjugates, provide valuable tools in PDT for the treatment of several diseases (Barata et al. 2015).
The use of polyethylene glycol (PEG) is also a popular approach to enhance the biocompatibility of hydrophobic drugs. In fact, there are several examples in literature on the functionalization of tetrapyrrolic macrocycles with different PEG chains for being used as PSs for PDT (Frederic and Lucienne 2012, Mariusz et al. 2012, Flávio et al. 2014). The introduction of PEG chains in a macrocycle has many advantages; besides 


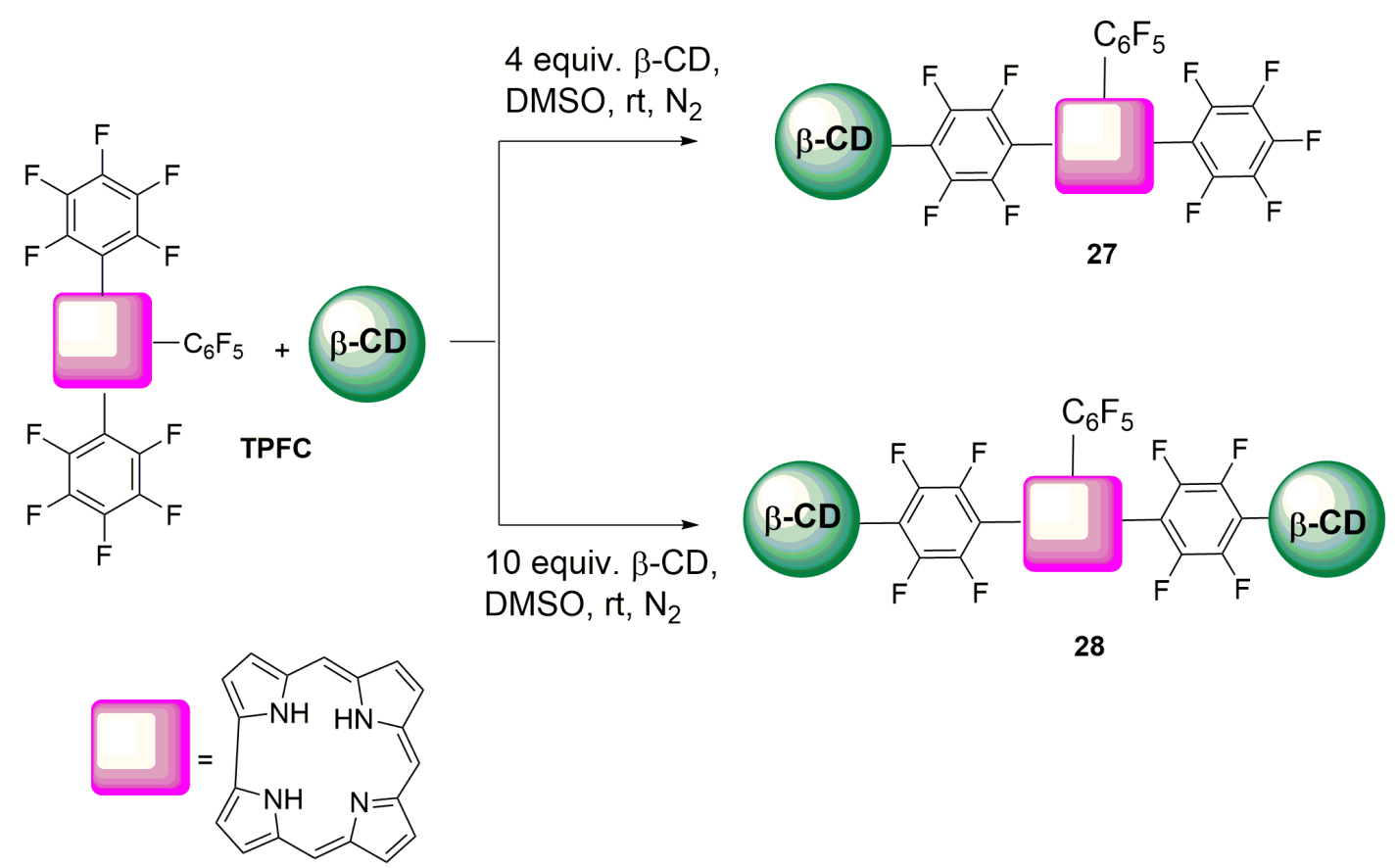

Figure 25 - Synthesis of corrole $\beta$-cyclodextrin conjugates Corr- $\beta$-CD 27 and Corr- $\beta$-CD 28.

improving the hydrophilicity of the drug it leads to a prolonged blood circulating life-time, it allows the minimization of non-specific uptake and it favors the enhanced permeability and retention (EPR) effect. These features combined together result in a higher cellular uptake of the drug at the tumor site (van Vlerken et al. 2007). A recent publication from Aveiro is related with the synthesis and in vitro evaluation of PEGcontaining ruthenium phthalocyanines ( $\left.\mathrm{RuL}_{2} \mathrm{PCs}\right)$ as PSs for PDT (Ferreira et al. 2017). The synthetic procedure to achieve these functional PSs was started by the synthesis of the ligands $\mathbf{L} 1, \mathbf{L} 2$ and $\mathbf{L 3}$ by convenient esterification of pyridine-3,5carboxylic acid according to figure 26 .

The synthesis of the $\mathrm{RuL}_{2} \mathrm{PCs}$ involved the metalation of free base phthalocyanine $\mathbf{H}_{2} \mathbf{P c}$ with $\mathrm{Ru}_{3}(\mathrm{CO})_{12}$ in benzonitrile affording the complex $\mathbf{R u}(\mathbf{P h C N})_{2} \mathbf{P c}$ bearing two benzonitrile ligands at the axial positions (Fig. 27); the presence of these ligands improved the macrocycle solubility in organic solvents and enabled its ready purification by standard column chromatography. Subsequent substitution of the axial nitrile ligands with the pyridine based ligands L1-3, bearing stronger affinity for the $\mathrm{Ru}$ ion, afforded the target bispyridylphthalocyanines RuL $\mathbf{2}$ Pcs.

Photophysical studies have shown that RuL $\mathbf{L}_{\mathbf{2}} \mathbf{P c s}$ containing 4-12 PEG chains with hydroxy, amino and ether terminal groups at their axial positions display high singlet oxygen generation quantum yields in $\operatorname{DMSO}\left(\varphi_{\Delta}=0.76\right)$ and in neat water $\left(\varphi_{\Delta}=0.48\right)$.

The efficacy of RuL $\mathbf{2}$ Pcs as PSs for PDT was evaluated against HT-1376 bladder cancer cells. Bladder cancer is especially suited for PDT studies since bladder is a round shaped transparent organ, easily accessible using an endoscope (Shackley et al. 2001). The results have shown that all RuL $\mathbf{L}_{\mathbf{2}} \mathbf{P c s}$ exhibited cellular uptake. $\mathbf{R u}\left(\mathbf{L}_{\mathbf{1}}\right)_{\mathbf{2}} \mathbf{P c}$ and $\mathbf{R u}\left(\mathbf{L}_{2}\right)_{2} \mathbf{P c}$ showed similar cellular uptake in HT-1376 cells, for the incubation with $5 \mu \mathrm{M}$ PS solutions, but $\mathbf{R u}\left(\mathbf{L}_{3}\right)_{2} \mathbf{P c}$ showed a considerably lower cellular uptake. This fact suggests that the presence of a higher number of PEG chains is responsible for a decrease in the cellular uptake 


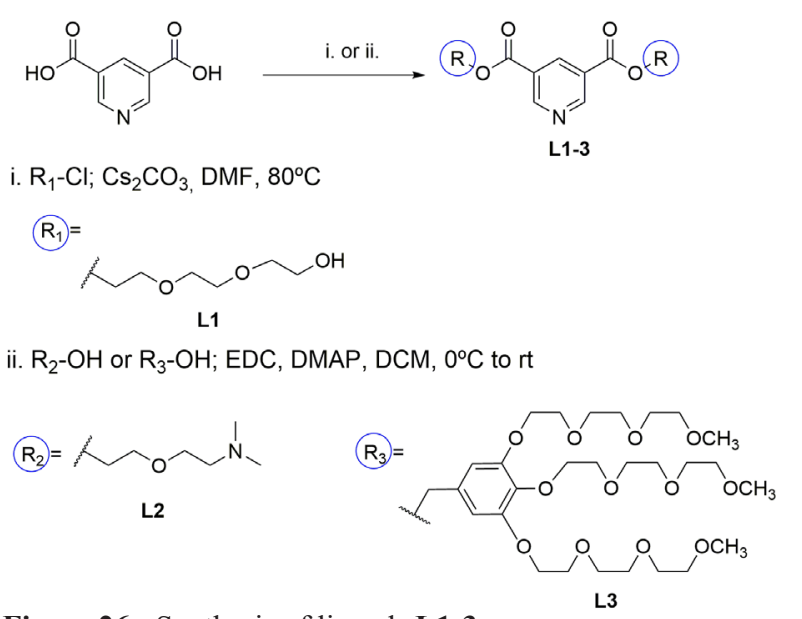

Figure 26 - Synthesis of ligands L1-3.

by HT-1376 cells. This may be a consequence of the higher hydrophilic character that hampers the crossing of the hydrophobic cellular membrane, if the process occurs by simple diffusion (Sun et al. 2014). Their phototoxic effects were evaluated $24 \mathrm{~h}$ after the irradiation of HT-1376 cells with red light. $\mathbf{R u}\left(\mathbf{L}_{1}\right)_{2} \mathbf{P c}$ and $\mathbf{R u}\left(\mathbf{L}_{2}\right)_{2} \mathbf{P c}$ showed similar phototoxic effects, with a decrease in cell viability at the maximum concentration tested $(5 \mu \mathrm{M})$. Surprisingly $\mathbf{R u}\left(\mathbf{L}_{3}\right)_{2} \mathbf{P c}$ produced a higher phototoxic effect despite its lower cellular uptake and so it was concluded that some other factor might play a role in the phototoxic effect of this compound. For instance, its improved hydrophilicity might result in higher solubility in the intracellular environment, with consequent improved generation of reactive oxygen species (ROS) (Ferreira et al. 2017).

Targeting DNA strategies has been also used to produce novel PSs with high affinity to cancer cells. It is known that drugs that target DNA and interfere with transcription and DNA replication, a major step in cell growth and division, might give rise to more efficient antitumor strategies (Aviv-Harel and Gross 2011). Cisplatin is a chemotherapeutic agent that is used in the treatment of solid tumors, being capable to interact non-covalently with nucleic acids. Its use in clinical cancer settings has been limited by unwanted toxic effects, low water-solubility and acquired resistance of cancer cells (Arnesano et al. 2013, Gomez-Ruiz et al. 2012). Nowadays, there are several organometallic compounds based on platinum units (e.g. cisplatin and its structural congeners), which have a key role in several cancer treatment protocols (Ho et al. 2003).

Porphyrin-platinum(II) conjugates have been synthesized, aiming to have on the same molecule the combination of the cytostatic activity promoted by the platinum moiety and the photodynamic activity conferred by porphyrin (Naue et al. 2009, $\mathrm{Xu}$ and Swavey 2011, Iengo et al. 2000).

Having this fact in mind, tetra-platinum(II)thiopyridylporphyrins 31 (Pt(II)-Por) and 32 (Pt(II)-Zn(II)Por 32 ) were synthetized respectively by coordination of the peripheral thiopyridyl units of the adequate free-base porphyrin $\mathbf{2 9}$ and of the corresponding zinc complex $\mathbf{3 0}$ with chloro(2,2'bipyridine)platinum(II) $\left[\mathrm{Pt}\left(\right.\right.$ bpy) $\left.\mathrm{Cl}_{2}\right]$ (Fig. 28) (Lourenço et al. 2015).

Spectroscopic studies of both platinum derivatives reveal their ability to interact with DNA from calf thymus and DNA of low molecular weight from salmon sperms, and also with the most abundant protein in human blood plasma, the human serum albumin (HSA). Herein, both tetra-platinum(II)-thiopyridylporphyrins $\mathbf{3 1}$ and 32 exhibit electrostatic surface binding with the negative phosphate groups of DNA. Similar to cationic-anionic binding with DNA, Pt(II)-Zn(II)Por 32 demonstrates a particular binding intercalation mode with DNA (Fig. 29). Photophysical studies demonstrated that both porphyrins are photostable and able to generate ${ }^{1} \mathrm{O}_{2}$ after light irradiation. Exposure of pMT123 plasmid DNA to tetra-platinum(II)-thiopyridylporphyrins 31 and 32 and irradiation with light lead to singlestrand breakage as determined by the conversion of the supercoiled form of the plasmid (form I) into the nicked circular form (form II). The Pt(II)-Zn(II)Por 32 demonstrates a particular intercalation binding 


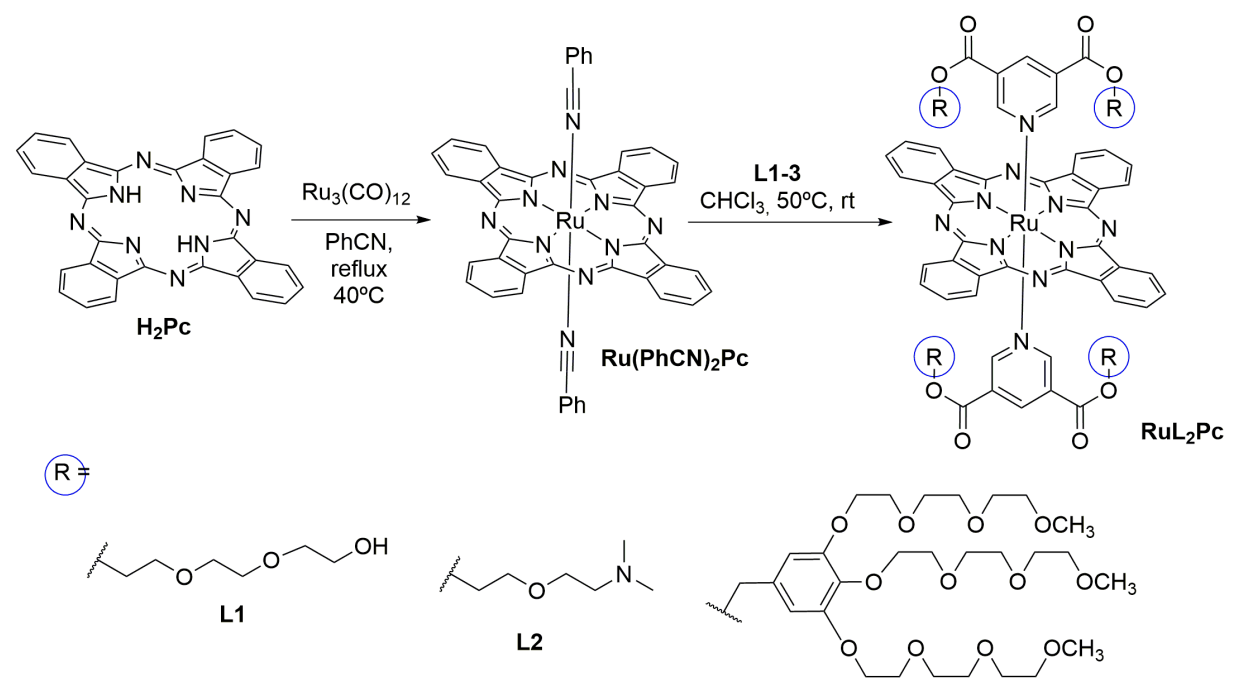

L3

Figure 27 - Synthetic strategy for PEG-containing ruthenium phthalocyanines ( $\left.\mathrm{RuL}_{2} \mathrm{PCs}\right)$.

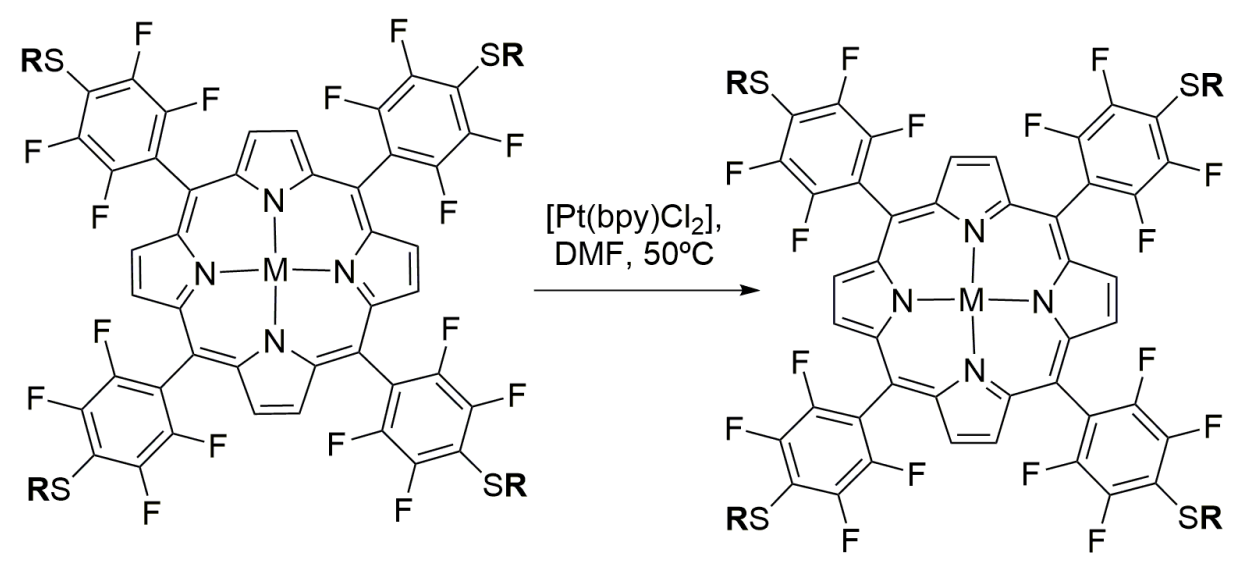

29: $\mathrm{M}=2 \mathrm{H}$

30: $M=Z n$

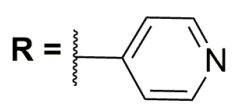

31: Pt(II)-Por

32: Pt(II)-Zn(II)Por<smiles></smiles>

$\Theta$

Figure 28 - Synthesis of tetra-platinum(II)-thiopyridylporphyrins $\mathbf{3 1}$ and $\mathbf{3 2}$.

mode with DNA and an ability to cleave DNA after photo-excitation. The strong pattern of interactions between DNA and the this porphyrin derivative could be a potential methodology to treat cancer cells mediated by PDT (Lourenço et al. 2015).

A similar methodology gave access to the bipyridyl platinum(II) corrole complexes Pt(II)-
Py-Corr 33 and 34 via coordination of the peripheral pyridyl moiety of corroles Py-Corr $\mathbf{3 5}$ and 36 with [ $\mathrm{Pt}\left(\right.$ bipy) $\left.\mathrm{Cl}_{2}\right]$ (Fig. 30). These new positional isomers were fully characterized and spectroscopic studies demonstrated the ability of Pt(II)-Py-Corr 33 and $\mathbf{3 4}$ to establish non-covalent 


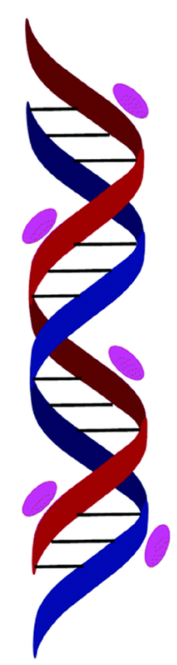

External binding of Pt(II)-Por 31 -DNA

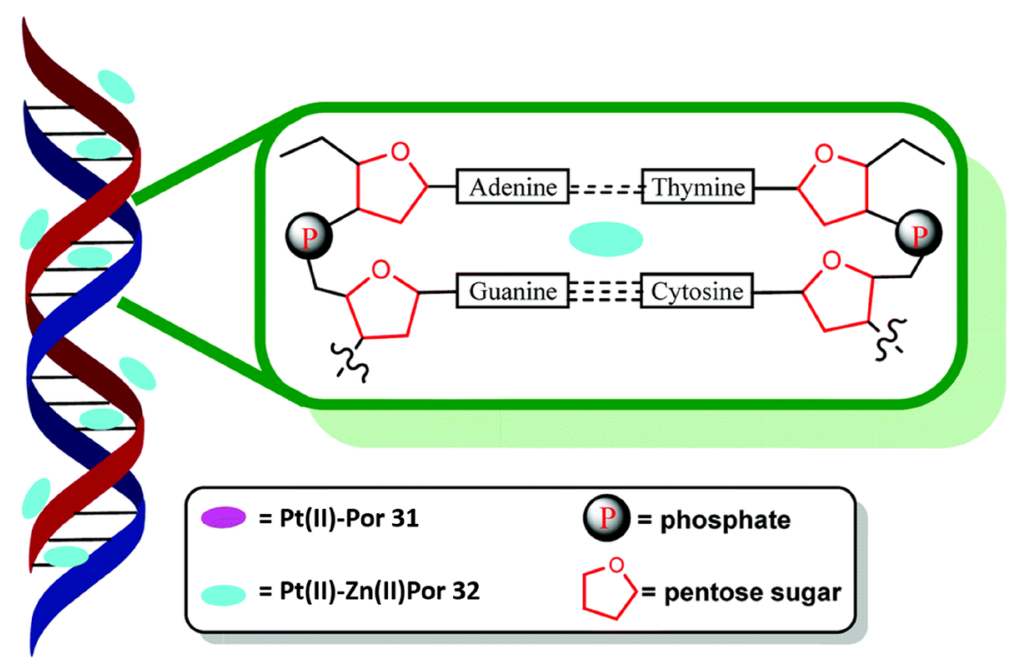

External binding and/or intercalation of Pt(II)-Zn(II)Por 32 -DNA

Figure 29 - Proposed possible binding modes of Pt(II)-Por 31 and Pt(II)-Zn(II)Por 32 with DNA. Reproduced from Lourenço et al. 2015 with permission of The Royal Society of Chemistry.

interactions with calf-thymus DNA (ct-DNA) and human serum albumin (HSA) (Iglesias et al. 2015).

Additionally, gel electrophoresis experiments demonstrated that Pt(II)-Py-Corr $\mathbf{3 3}$ and $\mathbf{3 4}$ are able to bind plasmid pMT123 DNA (pDNA), by inducing alterations on its secondary structure. These results seem to indicate that these corroles have potential as bio-supramolecular compounds for DNA-interaction applications, as, for example, PS in PDT of cancer (Iglesias et al. 2015).

In last decade, several groups have been pursuing an optimization of PDT applications by modification of the macrocycle core structure aiming to obtain compounds with adequate photophysical and hydrophobic/hydrophilic properties required for an ideal PS, increasing the tumor-specificity by developing target PS (Bonnett 2000, Zheng and Pandey 2008, Lange and Bednarski 2016). One of the approaches to reach selectivity to malignant cells is based on the synthesis of porphyrins bearing targeting moieties, like carbohydrate moieties (Zheng and Pandey 2008, Aksenova et al. 2003, Abrahamse and Hamblin 2016). The preparation of porphyrin-carbohydrate conjugates and the investigation of their ability to target carbohydrate - recognized proteins, which are known for their high expression in certain tumors, might be of great significance (Zhou et al. 2016, Hilf 2007, Wöhrle et al. 1998, Zheng and Pandey 2008). In fact, the conjugation of carbohydrates to porphyrin derivatives can increase their water solubility and bring better hydrophilic/hydrophobic ratios. Moreover, despite the better solubility in physiological media, glycoporphyrins interact with specific membrane receptors that can affect the cells' plasmatic life (Zheng and Pandey 2008).

In 2012, Soares et al. reported the photodynamic efficiency of the symmetric and asymmetric phthalocyanines Gal-Pht 37, GalPht 38 and Gal-Pht 39, bearing four or eight D-galactose units on HeLa carcinoma cells (Fig. 31) (Soares et al. 2012). The synthetic access to these phthalocyanines involved the tetramerization of the adequate glycophthalonitrile or glycophthalonitrile and phthalonitrile previously prepared, in $N, N$-dimethylaminoethanol (DMAE) at $140{ }^{\circ} \mathrm{C}$, in the presence of $\mathrm{ZnCl}_{2}$ (Soares et al. 2009, Ribeiro et al. 2006). 




Figure 30 - Synthetic approach to bipyridyl platinum(II) corrole complexes Pt(II)-Py-Corr 33 and 34.

Photophysical properties (namely electronic absorption spectra in DMEM with $10 \%$ of FBS and DMSO) and in vitro photodynamic activities of galacto-phtalocyanines prepared revealed that the asymmetric substitution of the sugars on the macrocycle Gal-Pht 39 is crucial to prevent the aggregation tendency of the molecules, when compared with symmetric Gal-Pht 37 and Gal-Pht 38. Gal-Pht 39 has a better cellular uptake, probably due to its amphiphilic character and, probably for these reason, Gal-Pht 39 showed to be very efficient and selective, producing higher photocytotoxicity on cancer cells than in non malignant $\mathrm{HaCaT}$ cells (Soares et al. 2012). The cell toxiticy after PDT treatment was dependent upon the light exposure level and Gal-Pht 39 concentration. For example, a high HaCaT surviving percentage of $69.2 \pm$ $7.5 \%$ could be reached with $5 \times 10-7 \mathrm{M}$, whereas in HeLa cells, the induced toxicity was of $23.4 \pm$ 5.2\%. These results, pointed out that Gal-Pht 39 provide a good photodynamic effect in HeLa cells with minimal photocytotoxicity to nontumoral cells at the concentrations of Gal-Pht $\mathbf{3 9}$ evaluated. It was also shown that this conjugate causes cell cycle arrest at the metaphase stage leading to multiple spindle poles, mitotic catastrophe, followed by apoptosis in cancer cells (Fig. 32). It is undeniable, that these results clearly indicate that Gal-Pht 39 is an excellent candidate drug for PDT, being able to induce selective tumor cell death (Soares et al. 2012).

In the same year, the synthesis and the photodynamic effect on Jurkat cells of the pentafluorophenylcorrole-D-galactose conjugates Gal-Corr 40 and 41 were reported. These conjugates were synthesized from the reaction of 5,10,15-tris(pentafluorophenyl)corrole TPFC and 1,2:3,4-di-O-isopropylidene-a-D-galactopyranose, according to Figure 33. The conjugate Gal-Corr 40 was obtained in higher yield (Cardote et al. 2012). The photophysical properties revealed that Gal-Corr 40 is a good fluorophore and it is able to generate singlet oxygen (Cardote et al. 2012).

The toxicity of TPFC and Gal-Corr $\mathbf{4 0}$ was studied by incubation of Jurkat cells with $10 \mu \mathrm{M}$ of each PS during periods of $1 \mathrm{~h}, 5 \mathrm{~h}$ and $24 \mathrm{~h}$ in the absence of light. Both corroles derivatives did not show any dark toxicity and the results obtained 


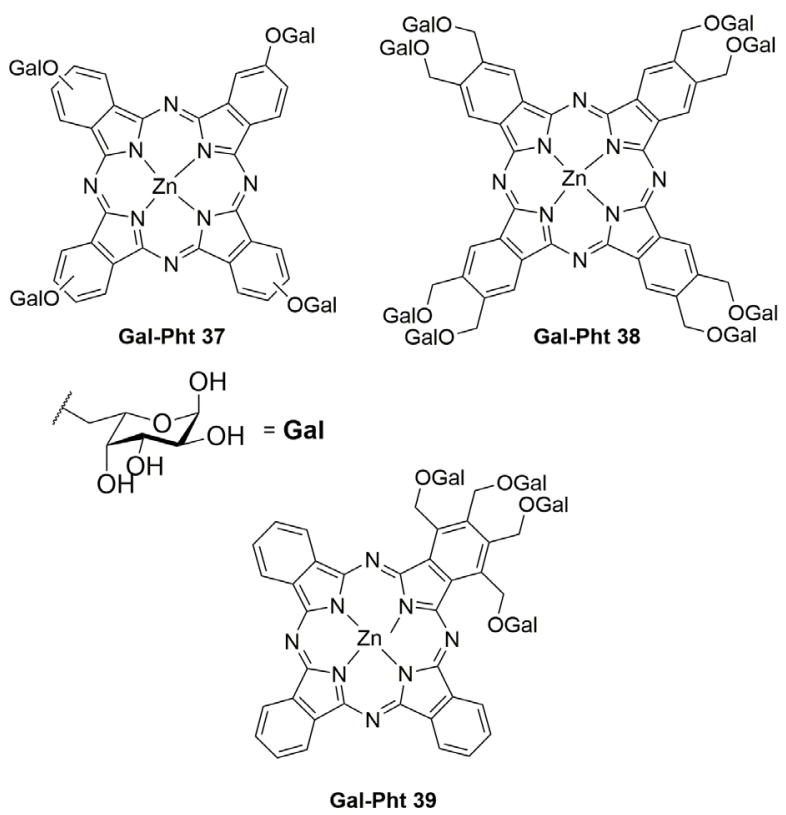

Figure 31 - Structures of galacto-phthalocyanines Gal-Pht 37, Gal-Pht 38 and Gal-Pht 39.

at the studied concentration were comparable to the controls. However, when irradiated, the two corrole derivatives promote almost the same total cell killing and there was an increase of about $10 \%$ of the apoptotic and necrotic processes when the period of incubation was $24 \mathrm{~h}$. These studies have unlocked the way to further investigation on glycocorroles to be tested in PDT or fluorescence diagnosis (Cardote et al. 2012).

HeLa carcinoma cells were also selected by Gomes et al. to evaluate the photodynamic effect of the glycochlorin conjugates 42a-d (Gomes et al. 2015). These conjugates were prepared previously by the cyclopropanation reaction of mesotetrakis(pentafluorophenyl)porphyrinatozinc(II) $\left(\mathbf{T P P F}_{\mathbf{2 0}}\right)$ with the adequate carbohydratesubstituted $\alpha$-diazoacetates in the presence of $\mathrm{CuCl}$ (Fig. 34) (Gomes et al. 2009). The cell viability study after PDT demonstrated that the glucose- and fructose-chlorin 42a and 42c have no cell selectivity, inactivating equally the non-tumoral $\mathrm{HaCaT}$ cells and the tumoral HeLa cells. On the other hand, the

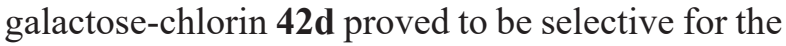

tumor cell line, inhibiting the growth of HeLa cells without affecting significantly the normal cell line (HaCaT).

In this study, it was also shown that galactosechlorin $\mathbf{4 2 d}$ is not toxic in the absence of light confirming that the main mechanism of action is related to the ${ }^{1} \mathrm{O}_{2}$ production and that this compound induces strongly cytoplasmic vacuolization and pronounced retraction on HeLa cells, whereas in $\mathrm{HaCaT}$ cells the damage observed is scarce (Fig. 35). These results strongly corroborate the high selectivity of galactose-chlorin $\mathbf{4 2 d}$ for the tumoral cells (Gomes et al. 2015).

In 2012 it was reported the synthetic access to water soluble porphyrin and phthalocyanine derivatives with, respectively, eight (Por-Gal ${ }_{8}$ 44) and sixteen (Pc-Gal ${ }_{16}$ 45) D-galactopyranose units (Fig. 36) (Silva et al. 2012). The key step on the synthetic access to these dendrimers involved the nucleophilic substitution of fluoride atoms of $\mathrm{TPPF}_{20}$ and of $\mathrm{ZnPcF}_{16}$ by the thiol groups of the protected galacto-dendritic unit 43. The presence of deprotected carbohydrate moieties in the porphyrin or phthalocyanine periphery, embodies hydrophilicity to these compounds, an important issue concerning drug administration. In addition, it was also shown that Por-Gal 84 and Pc-Gal ${ }_{16}$ 45 interact strongly with tryptophan residues of human albumin serum (HAS) and were able to produce with high efficiency singlet oxygen (Silva et al. 2012).

The in vitro photodynamic effect of $\mathrm{Pc}_{-\mathrm{Gal}_{16}}$ 45 in bladder cancer cells (HT-1376 and UM$\mathrm{UC}-3$ ) as well the role of PS-protein interactions was posteriorly reported (Pereira et al. 2014b). The study showed that Pc-Gal ${ }_{16} 45$ is a nontoxic compound per se but has high photocytotoxic efficiency in the two bladder cancer cell lines, related with its high ability to produce reactive oxygen species (ROS) and to induce oxidative stress (Fig. 37). Treatment with ROS quenchers demonstrated that cell death in bladder cancer cells 
is mediated by the production of ROS after PDT. Immediately after PDT with Pc - $\mathrm{Gal}_{16} 45$ there was an increase on the activity of antioxidant enzymes (SOD, CAT and GR antioxidant enzymes). Although a similar Pc-Gal 45 uptake was observed in the two bladder cancer cell lines, both GLUT1
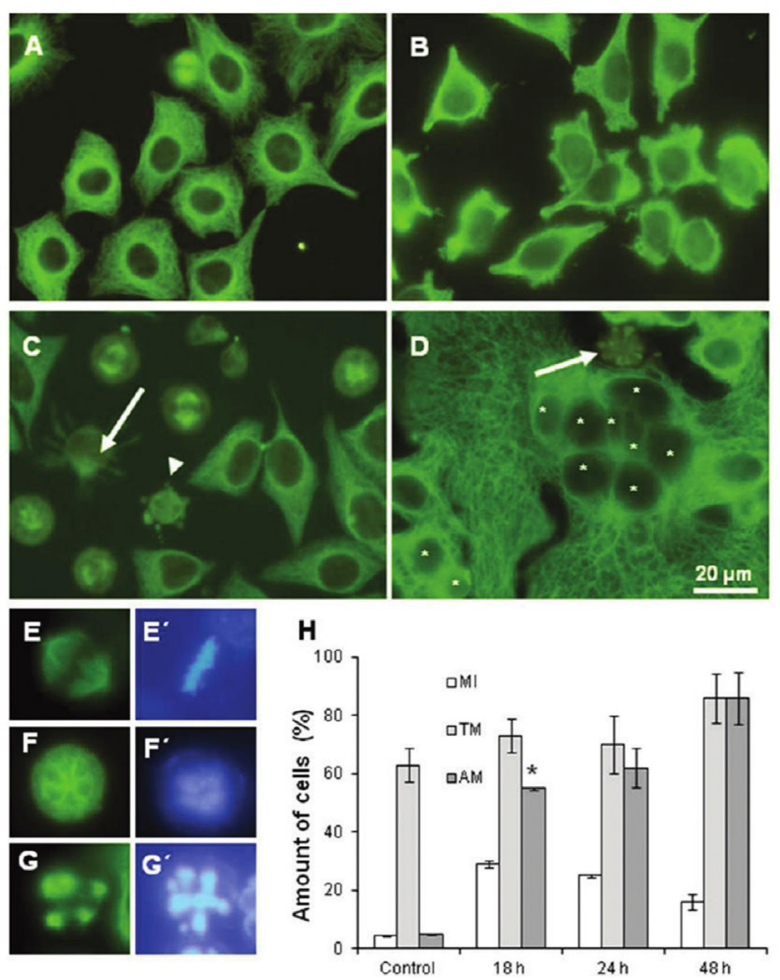

Figure 32 - Microtubule damage induced by Gal-Pht 39. (A) Control HeLa cells showing a well-developed network of MTs determined by tubulin immunolabeled and observed by fluorescence microscopy. Three hours after phototreatment $\left(5 \times 10^{-7} \mathrm{M}\right.$ of Gal-Pht 39 for $4 \mathrm{~h}$ and $15 \mathrm{~min}$ of red light irradiation) retraction and disorganization of MTs of cells in interphase could be observed (B). At $24 \mathrm{~h}$ after phototreatment (C) cells in metaphase showed abnormal mitotic spindles (arrow) as well as cells in apoptosis (arrowhead). At $48 \mathrm{~h}$ after phototreatment (D), giant polyploid and multinucleated (asterisks) cells appeared. (E-G) Details of a control (E) and abnormal mitotic spindles of HeLa cells $24 \mathrm{~h}$ after phototreatment $(\mathbf{F}, \mathbf{G}) .\left(\mathbf{E}^{\prime}-\mathbf{G}^{\prime}\right)$ The chromosomes stained with $\mathrm{H}-33258$ perfectly aligned in the control $\left(\mathbf{E}^{\prime}\right)$ or dispersed in the treated metaphase cells $\left(\mathbf{F}^{\prime}, \mathbf{G}^{\prime}\right)$. Scale bar: $20 \mu \mathrm{m}$. $(\mathbf{H})$ Cell blockage at 18,24 , and $48 \mathrm{~h}$ induced after photodynamic treatment with Gal-Pht 39. MI, mitotic index; TM, total metaphases; AM, abnormal metaphases; data correspond to mean values \pm standard deviation from three independent experiments $\left({ }^{*} p<0.05\right)$. Reproduced from Soares et al. 2012 with permission of The American Chemical Society. and galectin-1 may contribute for its specificity modulating the intracellular uptake. Knockdown of galectin-1 and GLUT1 in UM-UC-3 and HT-1376 cells, respectively, was associated with a marked decrease of Pc-Gal ${ }_{16} 45$ uptake and phototoxicity. Pc-Gal ${ }_{16} 45$ co-localization with galectin-1 and GLUT1 and/or generation of oxidative stress after Pc-Gal $_{16} 45$ photoactivation induces changes in the levels of these proteins. Together, these data demonstrated that galectin-1 and GLUT1 contribute for the efficacy of PDT mediated by Pc$\mathrm{Gal}_{16}$ 45. Although PDT with Pc-Gal ${ }_{16} 45$ induced an increase on the activity of antioxidant enzymes immediately after PDT, bladder cancer cells were unable to recover from the PDT-induced damage effects for at least $72 \mathrm{~h}$ after treatment. The results reported in this work showed that $\mathrm{Pc}-\mathrm{Gal}_{16} 45$ is a promising therapeutic agent for the treatment of bladder cancer, which is the fifth most common type of cancer with the highest rate of recurrence of any cancer (Pereira et al. 2014b).

Assuming that Por- $\mathrm{Gal}_{8} 44$ also can target the galactose-binding protein, galectin-1, overexpressed in many tumors tissues, in vitro and in vivo studies have been reported to prove the effectiveness of this PS in PDT of bladder cancer (Pereira et al. 2016b). As in the previous case, Por$\mathrm{Gal}_{8} 44$ had shown a specific uptake and induction of apoptotic cell death by generating oxidative stress and critical alterations in the cytoskeleton of bladder cancer cells overexpressing galectin-1, inducing alterations of F-actin organization. Moreover, the in vivo studies performed in a xenograft tumour model, which includes mice with UM-UC-3luc ${ }^{+}$cells (containing high levels of galectin-1) in the dorsum, had validated the ability of Por- $\mathrm{Gal}_{8} 44$ to be accumulated in the tumor tissue. PDT with Por-Gal 44 led to successful shrinkage of subcutaneously xenografted tumors after only a single administration of PS followed by a single exposure of light. This therapeutic approach was also able to induce in vivo changes 


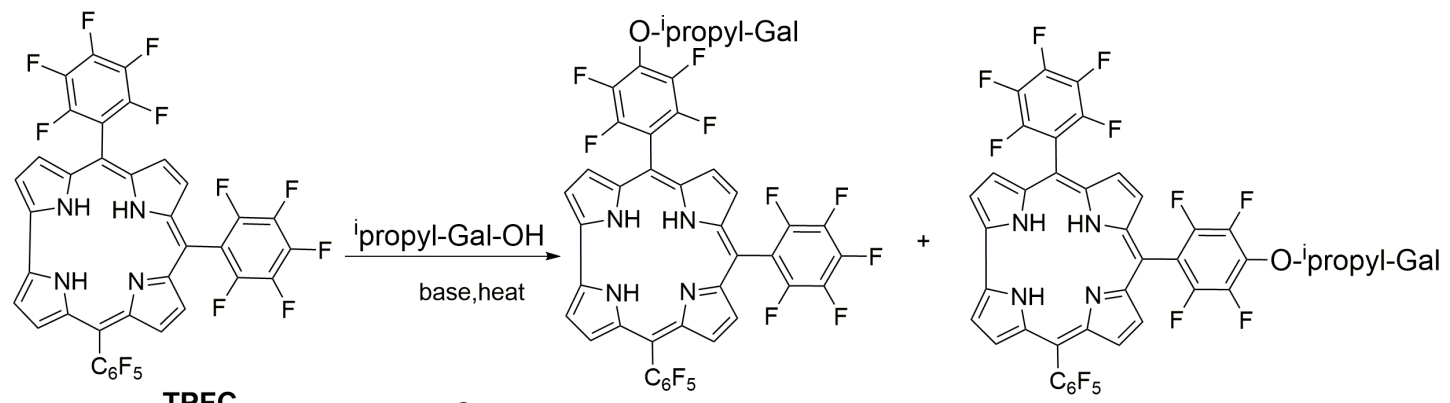

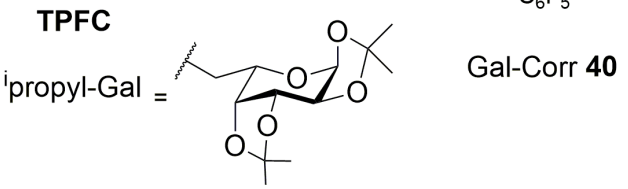

Gal-Corr 41

Figure 33 - Synthesis of pentafluorophenylcorrole-D-galactose conjugates Gal-Corr $\mathbf{4 0}$ and $\mathbf{4 1}$.

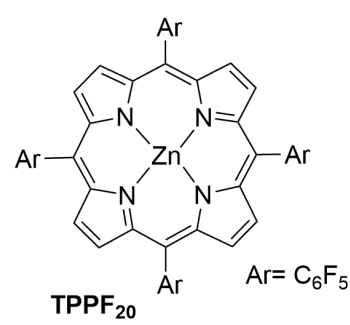<smiles>[R]OC(=O)/C=N\C</smiles>

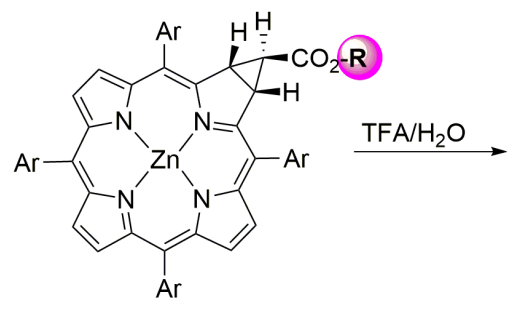

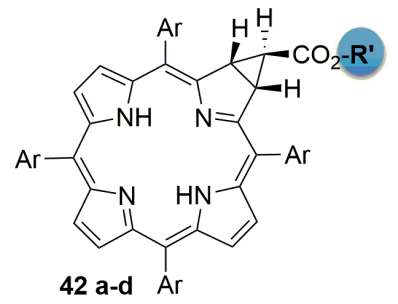

\section{$\mathbf{R}=$}

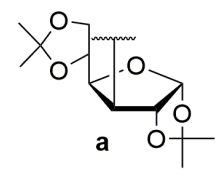<smiles>CC(C)CC1COC(OCc2ccccc2)C2OC1OC(C)(C)O2</smiles>
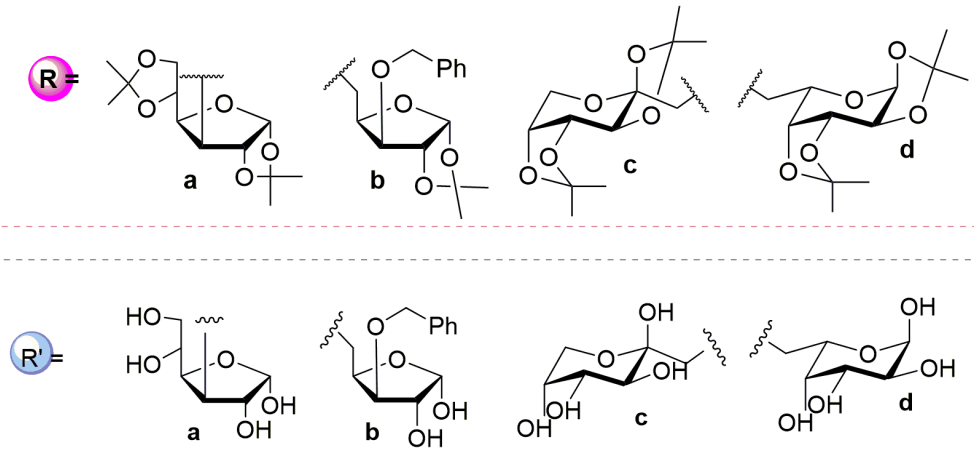

Figure 34 - Synthetic strategy for glycochlorin conjugates 42a-d.

in the distribution pattern of the cell adhesion protein E-cadherin, which is responsible to mediate cell-cell adhesion in epithelia and is its function is dependent on the actin cytoskeleton via proteins called catenins (Fig. 38) (Pereira et al. 2016b, van Roy and Berx 2008). So, it was demonstrated that the potential of PDT with Por- $\mathrm{Gal}_{8} 44$ seems to depend on the expression of galectin-1 and then on ROS formation and alterations on the cytoskeleton of cancer cells (Pereira et al. 2016b).
Considering these promising works, in 2016 it was reported the synthesis of the chlorin derivative Chl-Gal ${ }_{8} 46$ also conjugated with galactodendritic units (Figure 36) (Pereira et al. 2016a). The synthetic approach was also based on the nucleophilic substitution by the galacto-dendridic unit $\mathbf{4 3}$ of the $p$-fluorine atoms of the chlorin $\mathrm{ChlF}_{20}$; this chlorin was obtained from TPPF $_{20}$ through a 1,3-dipolar cycloaddition process as it was previously described by Cavaleiro's group (Silva et al. 1999, 2005). The results showed that this chlorin has excellent 


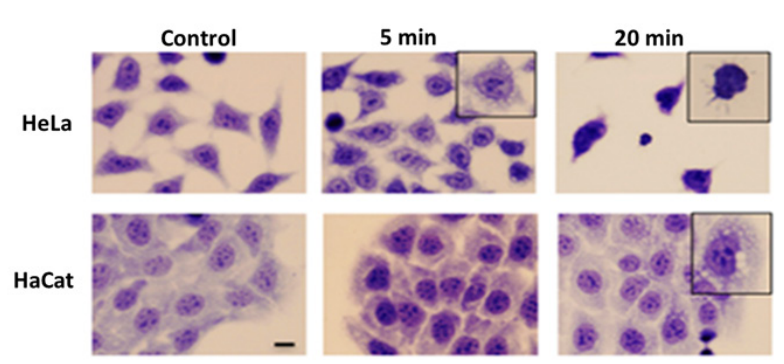

Figure 35 - Morphological changes induced by chlorin 42d on $\mathrm{HaCaT}$ and HeLa cell lines after being incubated for $4 \mathrm{~h}$ with a concentration of $1.0 \times 10^{-7} \mathrm{M}$ and subject to different irradiation times. After $24 \mathrm{~h}$ of light exposure, cells were fixed in cold methanol and stained with toluidine blue. Photographs are representative images of three different experiments for each condition. Scale bar: $10 \mu \mathrm{m}$. Reproduced from Gomes et al. 2015 with permission of The Royal Society of Chemistry.

photostability, high ability to generate singlet oxygen and to interact with the proteins galectin-1 and human serum albumin (HSA) (Pereira et al. 2016a). Besides the Chl-Gal 46 exhibits high absorption in the red region of the electromagnetic spectrum where tissue light penetration is rather high, which is an important requirement for PDT (Senge and Brandt 2011, Lu et al. 2015, Agostinis et al. 2011). The PDT efficiency of this derivative was tested in two bladder cancer cell lines derived from transitional cell carcinoma (HT-1376- and UM-UC-3). These in vitro studies revealed that once this PS is taken up by UM-UC-3 bladder cancer cells, it induces high cytotoxicity after only a single dose of light irradiation. Whereas, HT1376 bladder cancer cells revealed to be resistant to this therapeutic approach and for this reason a second light irradiation treatment was applied. The results had shown that the repeated PDT treatment enhanced in vitro photodynamic efficacy. This effect was also observed when PDT was applied in subcutaneous xenograft HT-1376 tumors (Fig. 39). The subcellular localization studies revealed that the enhanced phototoxicity in HT-1376 cancer cells seems to be due to the ability of Chl-Gal ${ }_{8} \mathbf{4 6}$ to accumulate in the mitochondria, via glucose transporter 1 (GLUT1), in the period between single and repeated irradiation. A PDT treatment using an extra dose of light irradiation and $\mathrm{Chl}-\mathrm{Gal}_{8}$ 46 as PS represents a promising strategy in treating resistant cancers in a clinical setting (Pereira et al. 2016a).

\section{FINAL REMARKS}

A few centuries ago scientists inquired themselves about the reason for blood being red and grass being green. In the last century that query was explained with the synthesis of the involved compounds. Since then researchers started looking for potential applications in several areas for the involved natural compounds or their synthetic analogues. Certainly the applications in Medicine are the most promising ones. Clinical approvals in a few cases took place and formulations are already available for treating neoplastic diseases and for the inactivation of microorganisms. This has been involving interdisciplinary studies from scientists from several working areas and in the end with the interest of clinical doctors from oncology, dermatology, ophthalmology and dentistry areas. The ideal compound in any case is not yet available. New working targets will be continued. And many scientists will be looking for that in future. Chemists will have a key position in the process of designing and synthesizing new derivatives. Certainly the situation tomorrow will be better than today's one.

\section{ACKNOWLEDGMENTS}

Thanks are due to the University of Aveiro, the Fundação para a Ciência e a Tecnologia (FCT), the European Union, QREN, FEDER and COMPETE for funding the QOPNA research unit (project PEst-C/QUI/UI0062/2013) and the Portuguese National NMR Network (RNRMN). Ana T.P.C. Gomes also thanks FCT for her research grant (SFRH/BPD/79521/2011). Thanks are also due to all students and colleagues involved in the authors' work. 


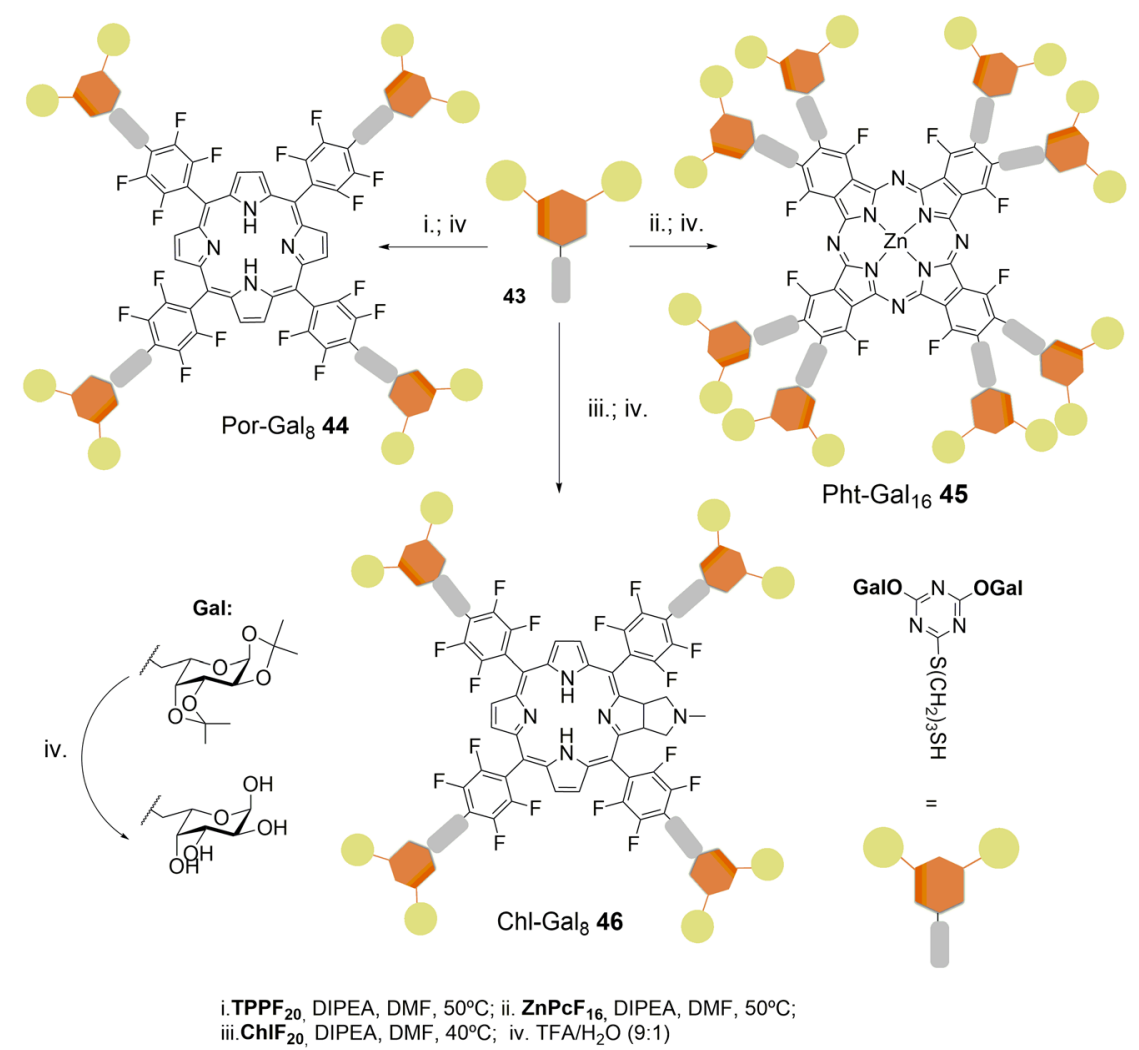

Figure 36 - Schematic representation for the synthesis of Por-Gal ${ }_{8} 44,{\mathrm{Pc}-\mathrm{Gal}_{16}} 45$ and $\mathrm{Chl}_{-\mathrm{Gal}_{8} 46 .}$

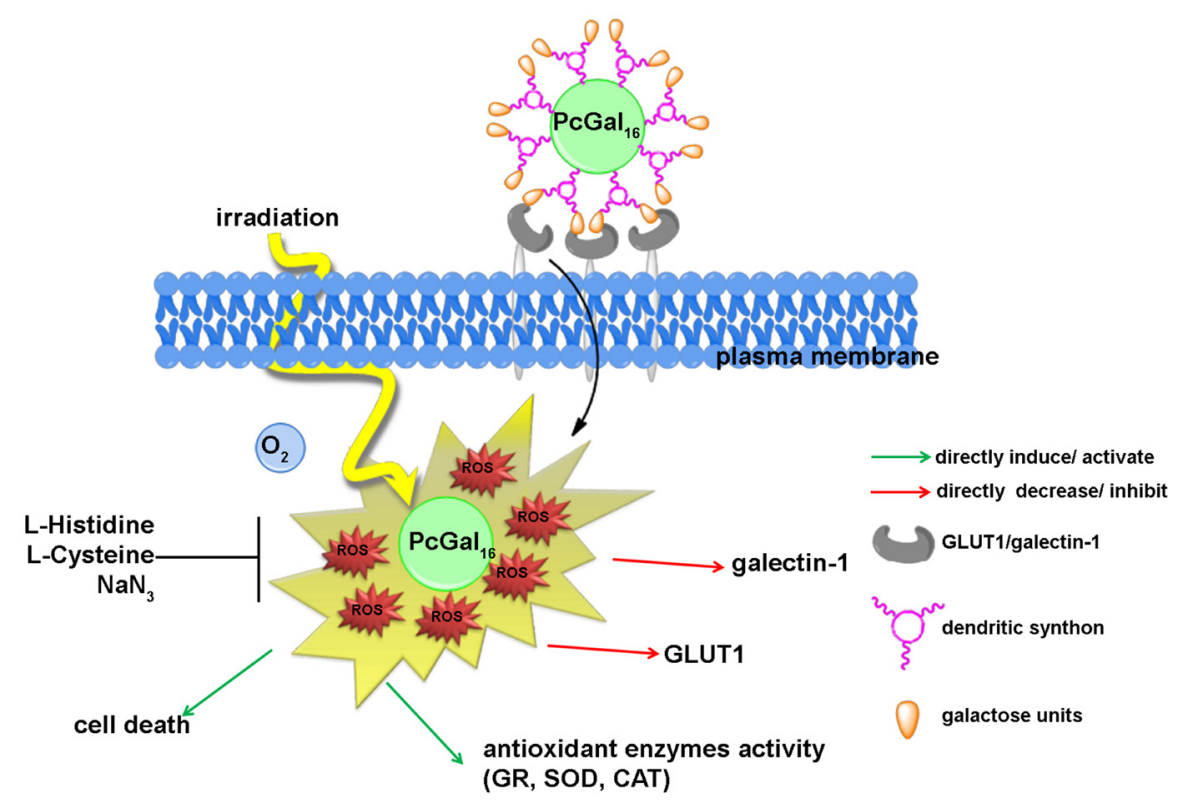

Figure 37 - Hypothetic illustration of phototoxicity of Pc-Gal ${ }_{16} 45$ in human bladder cancer cells. The uptake of Pht-Gal ${ }_{16} \mathbf{2 5}$ by bladder cancer cells is modulated by the presence of carbohydrate-binding proteins present at the cell surface (i.e. GLUT1 and galectin-1). Reproduced from Pereira et al. 2014b with permission of Public Library of Science. 

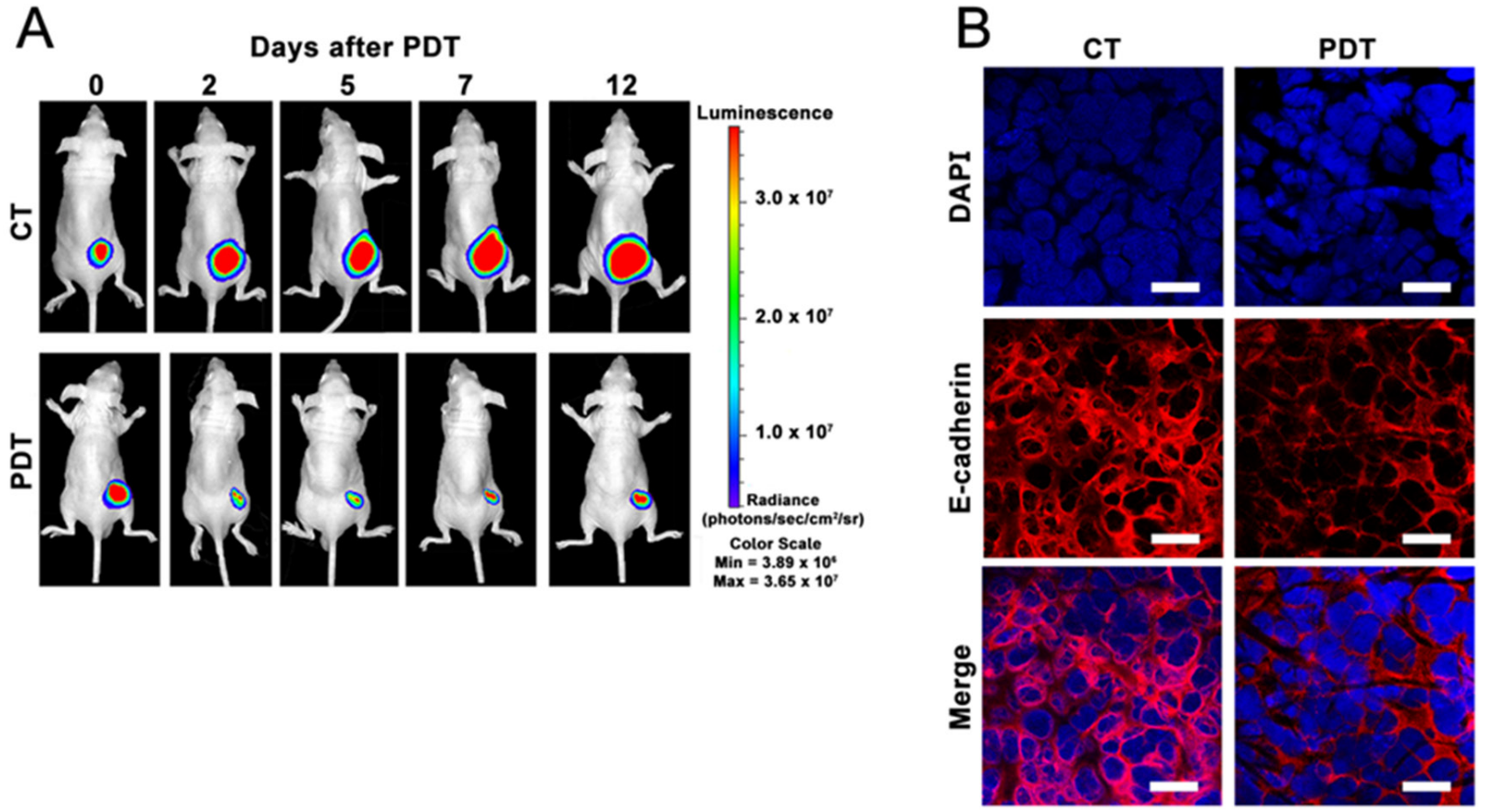

Figure 38 - (A) Representative bioluminescent images of mice at 2, 5, 7 and 12 days post PDT with Por-Gal 8 44. PDT 50.4 J/ $\mathrm{cm}^{2}$ was performed $24 \mathrm{~h}$ after intraperitoneal injection with $5 \mu \mathrm{mol} / \mathrm{kg}$ of Por-Gal ${ }_{8}$ 44. (B) Representative fluorescence images of E-cadherin protein (red) in UM-UC-3luc+ tumors of control and treated group, with DAPI staining the nucleus (blue). Scale bars, $20 \mu \mathrm{m}$. Reproduced from Pereira et al. 2016b with permission of Elsevier.

a)

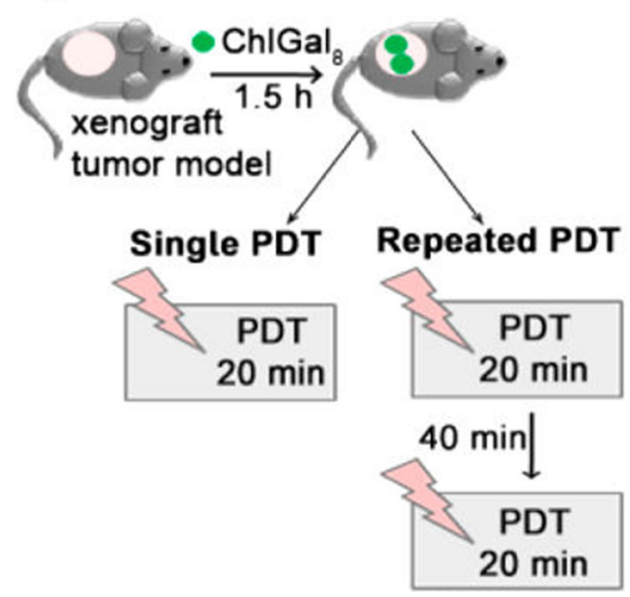

b)

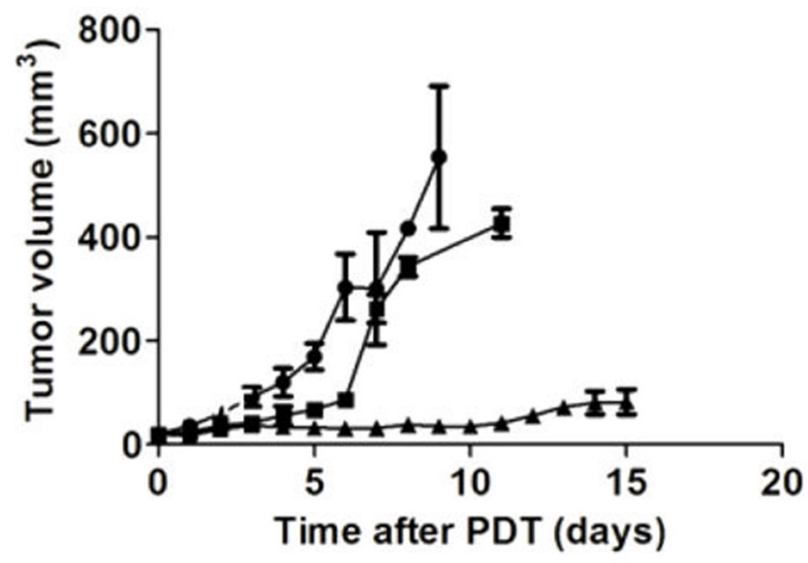

$\rightarrow$ Control $\rightarrow$ Single PDT $\neq$ Repeated PDT

Figure 39 - Repeated PDT treatment with ChlGal8 improves the in vivo photodynamic efficacy against HT-1376 tumors inoculated in nude mice. (a) Schematic illustration of single and repeated PDT experiments performed in vivo with Chl-Gal ${ }_{8}$ 46. (b) Tumor volumes in control mice and mice treated with single and repeated PDT at days 1-15 after treatment. Values are means \pm standard error of the mean ( $n=6$ mice per group). Reproduced from Pereira et al. 2016a with permission of The American Chemical Society. 


\section{REFERENCES}

ABRAHAMSE H AND HAMBLIN MICHAEL R. 2016. New photosensitizers for photodynamic therapy. Biochem $\mathrm{J}$ 473: 347-364.

ABRAHAMSE H, KRUGER CA, KADANYO S AND MISHRA A. 2017. Nanoparticles for Advanced Photodynamic Therapy of Cancer. Photomed Laser Surg 35: 581-588.

AGOSTINIS P ET AL. 2011. Photodynamic therapy of cancer: An update. CA Cancer J Clin 61: 250-281.

AKSENOVA AA, SEBYAKIN YL AND MIRONOV AF. 2003. Conjugates of Porphyrins with Carbohydrates. Bioorg Khim 29: 201-219.

ALLISON RR AND SIBATA CH. 2010. Oncologic photodynamic therapy photosensitizers: A clinical review. Photodiagnosis Photodyn Ther 7: 61-75.

ALMEIDA A, CUNHA A, FAUSTINO MAF, TOME AC AND NEVES MGPMS 2011. Porphyrins as Antimicrobial Photosensitizing Agents. In: Hamblin MR and Jori G (Eds), Photodynamic Inactivation of Microbial Pathogens: Medical and Environmental Applications. Cambrigde: Royal Society of Chemistry, p. 83-160.

ALVES E, COSTA L, CARVALHO CM, TOMÉ JP, FAUSTINO MA, NEVES MG, TOMÉ AC, CAVALEIRO JA, CUNHA Â AND ALMEIDA A. 2009. Charge effect on the photoinactivation of Gram-negative and Grampositive bacteria by cationic meso-substituted porphyrins. Bmc Microbiol 9: 70.

AMOR TB, TRONCHIN M, BORTOLOTTO L, VERDIGLIONE R AND JORI G. 1998. Porphyrins and Related Compounds as Photoactivatable Insecticides I. Phototoxic Activity of Hematoporphyrin Toward Ceratitis capitata and Bactrocera oleae. Photochem Photobiol 67: 206-211.

ANIOGO EC, GEORGE BPA AND ABRAHAMSE H. 2017. Phthalocyanine induced phototherapy coupled with Doxorubicin; a promising novel treatment for breast cancer. Expert Rev Anticancer Ther 17: 693-702.

ARNESANO F, LOSACCO M AND NATILE G. 2013. An Updated View of Cisplatin Transport. Eur J Inorg Chem 2013: 2701-2711.

ATTIA AE AND TAWFIK A. 2013. Photodynamic Therapy in Dermatology: What's New. In: Elsaie ML (Ed), Photodynamic Therapy: New Research. New York: Nova Science Publishers.

AVIV-HAREL I AND GROSS Z. 2011. Coordination chemistry of corroles with focus on main group elements. Coord Chem Rev 255: 717-736.

AZZOUZI AR, LEBDAI S, BENZAGHOU F AND STIEF C. 2015. Vascular-targeted photodynamic therapy with TOOKAD ${ }^{\circledR}$ Soluble in localized prostate cancer: standardization of the procedure. World J Urol 33: $937-$ 944.

BAE H ET AL. 2014. Development of functional biomaterials with micro- and nanoscale technologies for tissue engineering and drug delivery applications. J Tissue Eng Regen Med 8: 1-14.

BARATA JFB, NEVES MGPMS, FAUSTINO MAF, TOMÉ AC AND CAVALEIRO JAS. 2017. Strategies for Corrole Functionalization. Chem Rev 117: 3192-3253.

BARATA JFB, ZAMARRÓN A, NEVES MGPMS, FAUSTINO MAF, TOMÉ AC, CAVALEIRO JAS, RÖDER B, JUARRANZ Á AND SANZ-RODRÍGUEZ F. 2015. Photodynamic effects induced by mesotris(pentafluorophenyl)corrole and its cyclodextrin conjugates on cytoskeletal components of HeLa cells. Eur J Med Chem 92: 135-144.

BATTERSBY AR, FOOKES CJR, MATCHAM GWJ AND MCDONALD E. 1980. Biosynthesis of the pigments of life: formation of the macrocycle. Nature 285: 17.

BATTOGTOKH G AND KO YT. 2017. Mitochondrialtargeted photosensitizer-loaded folate-albumin nanoparticle for photodynamic therapy of cancer. Nanomedicine 13: 733-743.

BIRON E AND VOYER N. 2005. Synthesis of cationic porphyrin modified amino acids. Chem Commun, p. 46524654.

BONNETT R. 1995. Photosensitizers of the porphyrin and phthalocyanine series for photodynamic therapy. Chem Soc Rev 24: 19-33.

BONNETT R. 1999. Photodynamic therapy in historical perspective. Rev Contemp Pharmaco 10: 1-17.

BONNETT R. 2000. Chemical Aspects of Photodynamic Therapy. Gordon and Breach Science Publishers: Amsterdam, $324 \mathrm{p}$.

BONNETT R AND MARTINEZ G. 2001. Photobleaching of sensitisers used in photodynamic therapy. Tetrahedron 57 : 9513-9547.

BONNETT R, WHITE RD, WINFIELD UJ AND BERENBAUM MC. 1989. Hydroporphyrins Of The Meso-Tetra(Hydroxyphenyl)Porphyrin Series As Tumor Photosensitizers. Biochem J 261: 277-280.

BOYLE RW AND DOLPHIN D. 1996. Structure and biodistribution relationships of photodynamic sensitizers. Photochem Photobiol 64: 469-485.

BRANDIS A, MAZOR O, NEUMARK E, ROSENBACHBELKIN V, SALOMON Y AND SCHERZ A. 2005. Novel water-soluble bacteriochlorophyll derivatives for vasculartargeted photodynamic therapy: Synthesis, solubility, phototoxicity and the effect of serum proteins. Photochem Photobiol 81: 983-993.

BULLOUS AJ, ALONSO CMA AND BOYLE RW. 2011. Photosensitiser-antibody conjugates for photodynamic therapy. Photoch Photobio Sci 10: 721-750. 
CALVETE MJFG, GOMES ATP AND MOURA NMM. 2009. Chlorins in Photodynamic Therapy - Synthesis and applications. Rev Virtual Quim 1: 92-103.

CARDOTE TAF, BARATA JFB, FAUSTINO MAF, PREUß A, NEVES MGPMS, CAVALEIRO JAS, RAMOS CIV, SANTANA-MARQUES MGO AND RÖDER B. 2012. Pentafluorophenylcorrole-d-galactose conjugates. Tetrahedron Lett 53: 6388-6393.

CARRÉ V, GAUD O, SYLVAIN I, BOURDON O, SPIRO M, BIAIS J, GRANET R, KRAUSZ P AND GUILLOTON M. 1999. Fungicidal properties of mesoarylglycosylporphyrins: influence of sugar substituents on photoinduced damage in the yeast Saccharomyces cerevisiœ. J Photochem Photobiol B 48: 57-62.

CERQUEIRA A, MOURA N, SERRA V, FAUSTINO M, TOMÉ A, CAVALEIRO J AND NEVES M. 2017. $\beta$-Formyl- and $\beta$-Vinylporphyrins: Magic Building Blocks for Novel Porphyrin Derivatives. Molecules 22: 1269.

CHILAKAMARTHI U AND LINGAMALLU G. 2017. Photodynamic Therapy: Past, Present and Future.

CHOI YM, ADELZADEH L AND WU JJ. 2015. Photodynamic therapy for psoriasis. Dermatolog Treat 26: 202-207.

CHOUDHARY S, NOURI K AND ELSAIE ML. 2009. Photodynamic therapy in dermatology: a review. Lasers Med Sci 24: 971-980.

DE OLIVEIRA KT, SILVA AMS, TOMÉ AC, NEVES MGPMS, NERI CR, GARCIA VS, SERRA OA, IAMAMOTO Y AND CAVALEIRO JAS. 2008. Synthesis of new amphiphilic chlorin derivatives from protoporphyrin-IX dimethyl ester. Tetrahedron 64: 87098715.

DENIS T AND HAMBLIN M. 2013. History and Fundamentals of Photodynamic Therapy. In: Hamblin MR and Huang YY (Eds), Handbook of Photomedicine. Boca Raton, Florida: CRC Press, p. 35-42.

DOUGHERTY TJ. 1993. Photodynamic Therapy. Photochem Photobiol 58: 895-900.

DRABKIN DL. 1978. Selected Landmarks in the History of Porphyrins and Their Biologically Functional Derivatives. In: Dolphin D (Ed), The Porphyrins. New York: Academic Press, p. 29-83.

EMERSON H. 1933. Sunlight and Health. Am J Public Health Nations Health 23: 437-440.

FALCIONI R, SACCHI A, RESAU J AND KENNEL SJ. 1988. Monoclonal Antibody to Human Carcinomaassociated Protein Complex: Quantitation in Normal and Tumor Tissue. Cancer Res 48: 816-821.

FAUSTINO MAF, NEVES GPMS, CAVALEIRO JAS, NEUMANN M, BRAUER HD AND JORI G. 2000. Part 2. meso-tetraphenylporphyrin dimer derivatives as potential photosensitizers in photodynamic therapy. Photochem Photobiol 72: 217-225.
FAUSTINO MAF, NEVES MGPMS, VICENTE MGH, CAVALEIRO JAS, NEUMANN M, BRAUER H-D AND JORI G. 1997. Meso-Tetraphenylporphyrin Dimer Derivative as a Potential Photosensitizer in Photodynamic Therapy. Photochem Photobiol 66: 405-412.

FERREIRA J, PINA J, RIBEIRO CAF, FERNANDES $\mathrm{R}$, TOME JPC, RODRIGUEZ-MORGADE MS AND TORRES T. 2017. PEG-containing ruthenium phthalocyanines as photosensitizers for photodynamic therapy: synthesis, characterization and in vitro evaluation. J Mater Chem B 5: 5862-5869.

FLÁVIO F, PATRÍCIA MRP, SANDRINA S, JOSÉ ASC AND JOAO PCT. 2014. Porphyrins and Phthalocyanines Decorated with Dendrimers: Synthesis and Biomedical Applications. Curr Org Synth 11: 110-126.

FREDERIC S AND LUCIENNE JJ. 2012. Drug Targeting Strategies for Photodynamic Therapy. Anticancer Agents Med Chem 12: 500-525.

GAD F, ZAHRA T, FRANCIS KP, HASAN T AND HAMBLIN MR. 2004. Targeted photodynamic therapy of established soft-tissue infections in mice. Photoch Photobio Sci 3: 451-458.

GOMES A ET AL. 2009. Synthesis of new glycoporphyrin derivatives through carbohydrate-substituted alphadiazoacetates. J Porphyr Phthalocya 13: 247-255.

GOMES A, FAUSTINO MAF, NEVES M, FERREIRA VF, JUARRANZ A, CAVALEIROA JAS AND SANZRODRIGUEZ F. 2015. Photodynamic effect of glycochlorin conjugates in human cancer epithelial cells. Rsc Adv 5: 33496-33502.

GÓMEZ-RUIZ S, MAKSIMOVIC-IVANIC DM, MIJATOVIC S AND KALUDEROVIC GN. 2012. On the Discovery, Biological Effects, and Use of Cisplatin and Metallocenes in Anticancer Chemotherapy. Bioinorg Chem Appl 2012: 14.

GOMI S, NISHIZUKA T, USHIRODA O, UCHIDA N, TAKAHASHI H AND SUMI S. 1998. The structures of mono-L-aspartyl chlorin e6 and its related compounds. Heterocycles 48: 2231-2243.

HAMBLIN MR AND NEWMAN EL. 1994. Photosensitizer targeting in photodynamic therapy I. Conjugates of haematoporphyrin with albumin and transferrin. J Photochem Photobiol B 26: 45-56.

HILF R. 2007. Mitochondria are targets of photodynamic therapy. J Bioenerg Biomembr 39: 85-89.

HO YP, AU-YEUNG SCF AND TO KKW. 2003. Platinumbased anticancer agents: Innovative design strategies and biological perspectives. Med Res Rev 23: 633-655.

HORLINGS RK, TERRA JB AND WITJES MJH. 2015. mTHPC mediated, systemic photodynamic therapy (PDT) for nonmelanoma skin cancers: Case and literature review. Lasers Surg Med 47: 779-787. 
HUDSON R, CARCENAC M, SMITH K, MADDEN L, CLARKE OJ, PELEGRIN A, GREENMAN J AND BOYLE RW. 2005. The development and characterisation of porphyrin isothiocyanate-monoclonal antibody conjugates for photoimmunotherapy. Br J Cancer 92: 1442-1449.

IENGO E, MILANI B, ZANGRANDO E, GEREMIA S AND ALESSIO E. 2000. Novel ruthenium building blocks for the efficient modular construction of heterobimetallic molecular squares of porphyrins. Angew Chem Int Edit 39: 1096-1099.

IGLESIAS BA, BARATA JFB, PEREIRA PMR, GIRÃO H, FERNANDES R, TOMÉ JPC, NEVES MGPMS AND CAVALEIRO JAS. 2015. New platinum(II)-bipyridyl corrole complexes: Synthesis, characterization and binding studies with DNA and HSA. J Inorg Biochem 153: 32-41.

JIAN TH, KAZUHIKO I, KENJI Y, TSUTOMU II AND SEIJI S. 1998. New Organic Gelalors Bearing a Porphyrin Group: A New Strategy to Create Ordered Porphyrin Assemblies. Chem Lett 27: 871-872.

JOSEFSEN LB AND BOYLE RW. 2008. Photodynamic therapy: novel third-generation photosensitizers one step closer? Br J Clin Pharmacol 154: 1-3.

JUARRANZ Á, JAÉN P, SANZ-RODRÍGUEZ F, CUEVAS J AND GONZÁLEZ S. 2008. Photodynamic therapy of cancer. Basic principles and applications. Clin Transl Oncol 10: 148-154.

KADISH KM, SMITH KM AND GUILARD R. 2010. Handbook of porphyrin science-with applications to chemistry, physics, materials science, engineering, biology and medicine. In: Kadish KM, Smith KM and Guilard R (Eds), Singapore: World Scientific Pub. Co.

KEYAL U, BHATTA AK AND WANG XL. 2016. Photodynamic therapy for the treatment of different severity of acne: A systematic review. Photodiagnosis Photodyn Ther 14: 191-199.

KRATZ F. 2008. Albumin as a drug carrier: Design of prodrugs, drug conjugates and nanoparticles. J Control Release 132: 171-183.

KUDARHA RR AND SAWANT KK. 2017. Albumin based versatile multifunctional nanocarriers for cancer therapy: Fabrication, surface modification, multimodal therapeutics and imaging approaches. Mater Sci Eng C Mater Biol Appl 81: 607-626.

KUMAR M AND KUMAR S. 2017. Liquid crystals in photovoltaics: a new generation of organic photovoltaics. Polymer Journal 49: 85-111.

LANGE C AND BEDNARSKI PJ. 2016. Photosensitizers for Photodynamic Therapy: Photochemistry in the Service of Oncology. Curr Pharm Design 22: 6956-6974.

LIPSON RL, BALDES EJ AND OLSEN AM. 1961. The Use of a Derivative of Hematoporphyrin in Tumor Detection. J Natl Cancer Inst 26: 1-11.
LOURENÇO LMO, IGLESIAS BA, PEREIRA PMR, GIRAO H, FERNANDES R, NEVES MGPMS, CAVALEIRO JAS AND TOME JPC. 2015. Synthesis, characterization and biomolecule-binding properties of novel tetra-platinum(ii)thiopyridylporphyrins. Dalton T 44: 530-538.

LOURENÇO LMO, PEREIRA PMR, MACIEL E, VALEGA M, DOMINGUES FMJ, DOMINGUES MRM, NEVES MGPMS, CAVALEIRO JAS, FERNANDES R AND TOME JPC. 2014. Amphiphilic phthalocyaninecyclodextrin conjugates for cancer photodynamic therapy. Chem Commun 50: 8363-8366.

LU K, HE C AND LIN W. 2015. A Chlorin-Based Nanoscale Metal-Organic Framework for Photodynamic Therapy of Colon Cancers. J Am Chem Soc 137: 7600-7603.

MA X, FENG HH, LIANG CY, LIU XJ, ZENG FY AND WANG Y. 2017. Mesoporous silica as micro/nano-carrier: From passive to active cargo delivery, a mini review. J Mater Sci Technol 33: 1067-1074.

MACDONALD IJ AND DOUGHERTY TJ. 2001. Basic principles of photodynamic therapy. J Porphyr Phthalocya 5: 105-129.

MAEDA H, WU J, SAWA T, MATSUMURA Y AND HORI K. 2000. Tumor vascular permeability and the EPR effect in macromolecular therapeutics: a review. J Control Release 65: 271-284.

MANG TS. 2004. Lasers and light sources for PDT: past, present and future. Photodiagnosis Photodyn Ther 1: 43-48.

MARCUS SL. 1992. Clinical Photodynamic Therapy: The Continuing Evolution. In: Henderson B and Dougherty TJ (Eds), Photodynamic Therapy, New York: Marcel Dekker Inc.

MARIUSZ K, MONIKA D AND MARIA N. 2012. Nanostructural Hybrid Sensitizers for Photodynamic Therapy. Curr Pharm Design 18: 2607-2621.

MAZZAGLIA A, ANGELINI N, DARCY R, DONOHUE R, LOMBARDO D, MICALI N, SCIORTINO MT, VILLARI V AND SCOLARO LM. 2003. Novel Heterotopic Colloids of Anionic Porphyrins Entangled in Cationic Amphiphilic Cyclodextrins: Spectroscopic Investigation and Intracellular Delivery. Chem Eur J 9: 5762-5769.

MCCORMICK BPP, PANSA MF, SANABRIA LNM, CARVALHO CMB, FAUSTINO MAF, NEVES M, CAVALEIRO JAS, VITTAR NBR AND RIVAROLA VA. 2014. Cationic porphyrin derivatives for application in photodynamic therapy of cancer. Laser Phys 24: 4560345611.

MILGROM LR. 1997. The Colours of Life: An Introduction to the Chemistry of Porphyrins and Related Compounds. Oxford: Oxford University Press.

MOORE CM ET AL. 2015. Determination of optimal drug dose and light dose index to achieve minimally invasive focal ablation of localised prostate cancer using WST11- 
vascular-targeted photodynamic (VTP) therapy. BJU Int 116: 888-896.

MORGAN AR, PANGKA VS AND DOLPHIN D. 1984. Ready syntheses of benzoporphyrins via Diels-Alder reactions with protoporphyrin IX. J Chem Soc, Chem Commun, p. 1047-1048.

MORGAN J AND OSEROFF AR. 2001. Mitochondria-based photodynamic anti-cancer therapy. Adv Drug Deliv Rev 49: 71-86.

MOSER JG. 1998. Photodynamic Tumor Therapy. Definitions and General Properties of $2^{\text {nd }}$ and $3^{\text {rd }}$ generation photosensitizers, Amsterdam: Overseas Publishers.

NAUE JA, TOMA SH, BONACIN JA, ARAKI K AND TOMA HE. 2009. Probing the binding of tetraplatinum(pyridyl) porphyrin complexes to DNA by means of surface plasmon resonance. J Inorg Biochem 103: 182-189.

OLIVEIRA A, ALMEIDA A, CARVALHO CMB, TOMÉ JPC, FAUSTINO MAF, NEVES MGPMS, TOMÉ AC, CAVALEIRO JAS AND CUNHA Â. 2009. Porphyrin derivatives as photosensitizers for the inactivation of Bacillus cereus endospores. J Appl Microbiol 106: 19861995.

PANDEY RK, SUMLIN AB, CONSTANTINE S, AOUDIA M, POTTER WR, BELLNIER DA, HENDERSON BW, RODGERS MA, SMITH KM AND DOUGHERTY TJ. 1996. Alkyl Ether Analogs of Chlorophyll-a Derivatives: Part 1. Synthesis, Photophysical Properties and Photodynamic Efficacy. Photochem Photobiol 64: 194204.

PAOLESSE R, NARDIS S, MONTI D, STEFANELLI M AND DI NATALE C. 2017. Porphyrinoids for Chemical Sensor Applications. Chem Rev 117: 2517-2583.

PENG L, LIU S, FENG A AND YUAN J. 2017. Polymeric Nanocarriers Based on Cyclodextrins for Drug Delivery: Host-Guest Interaction as Stimuli Responsive Linker. Mol Pharm 14: 2475-2486.

PEREIRA PMR, CARVALHO JJ, SILVA S, CAVALEIRO JAS, SCHNEIDER RJ, FERNANDES R AND TOME JPC. 2014a. Porphyrin conjugated with serum albumins and monoclonal antibodies boosts efficiency in targeted destruction of human bladder cancer cells. Org Biomol Chem 12: 1804-1811.

PEREIRA PMR, KORSAK B, SARMENTO B, SCHNEIDER RJ, FERNANDES R AND TOME JPC. 2015. Antibodies armed with photosensitizers: from chemical synthesis to photobiological applications. Org Biomol Chem 13: 25182529.

PEREIRA PMR, SILVA S, BISPO M, ZUZARTE M, GOMES C, GIRÃO H, CAVALEIRO JAS, RIBEIRO CAF, TOMÉ JPC AND FERNANDES R. 2016a. Mitochondria-Targeted Photodynamic Therapy with a Galactodendritic Chlorin to Enhance Cell Death in Resistant Bladder Cancer Cells. Bioconjugate Chem 27: 2762-2769.
PEREIRA PMR, SILVA S, CAVALEIRO JAS, RIBEIRO CAF, TOMÉ JPC AND FERNANDES R. 2014b. Galactodendritic Phthalocyanine Targets CarbohydrateBinding Proteins Enhancing Photodynamic Therapy. PLoS ONE 9: e95529.

PEREIRA PMR, SILVA S, RAMALHO JS, GOMES CM, GIRÃO H, CAVALEIRO JAS, RIBEIRO CAF, TOMÉ JPC AND FERNANDES R. 2016b. The role of galectin-1 in in vitro and in vivo photodynamic therapy with a galactodendritic porphyrin. Eur J Cancer 68: 60-69.

PETRILLI R ET AL. 2013. Nanoparticles of Lyotropic Liquid Crystals: A Novel Strategy for the Topical Delivery of a Chlorin Derivative for Photodynamic Therapy of Skin Cancer. Curr Nanosci 9: 434-441.

PLAETZER K, KRAMMER B, BERLANDA J, BERR F AND KIESSLICH T. 2009. Photophysics and photochemistry of photodynamic therapy: fundamental aspects. Lasers Med Sci 24: 259-268.

RAPHAEL S, LORAINE T, CELINE F, REGIS V, NOEMIE T, JULIEN G, FRANCOIS G AND MURIEL BH. 2006. Recent Improvements in the Use of Synthetic Peptides for a Selective Photodynamic Therapy. Anticancer Agents Med Chem 6: 469-488.

RIBEIRO AO, TOMÉ JPC, NEVES MGPMS, TOMÉ AC, CAVALEIRO JAS, IAMAMOTO Y AND TORRES T. 2006. [1,2,3,4-Tetrakis( $\alpha / \beta$-d-galactopyranos-6-yl) phthalocyaninato]zinc(II): a water-soluble phthalocyanine. Tetrahedron Lett 47: 9177-9180.

ROELANDTS R. 2002. The history of phototherapy: Something new under the sun? J Am Acad Dermatol 46: 926-930.

SCHERZ A AND SALOMON Y. 2013. The Story of Tookad: From Bench to Bedside. In: Hamblin MR and Huang YY (Eds), Handbook of Photomedicine. Boca Raton, Florida: CRC Press, p. 435-450.

SENGE MO. 2012. mTHPC - A drug on its way from second to third generation photosensitizer? Photodiagnosis Photodyn Ther 9: 170-179.

SENGE MO AND BRANDT JC. 2011. Temoporfin (Foscan ${ }^{\circledR}$, 5,10,15,20-Tetra(m-hydroxyphenyl)chlorin) -A Secondgeneration Photosensitizer. Photochem Photobiol 87: 1240-1296.

SERRA VV ET AL. 2009. Synthesis and Biological Evaluation of Novel Chalcone-Porphyrin Conjugates. Acta Chim Slov 56: 603-611.

SERRA VV, ZAMARRÓN A, FAUSTINO MAF, IGLESIASDE-LA-CRUZ MC, BLÁZQUEZ A, RODRIGUES JMM, NEVES MGPMS, CAVALEIRO JAS, JUARRANZ A AND SANZ-RODRÍGUEZ F. 2010. New porphyrin amino acid conjugates: Synthesis and photodynamic effect in human epithelial cells. Bioorgan Med Chem 18: 61706178. 
SHACKLEY DC, BRIGGS C, WHITEHURST C, BETTS CD, O'FLYNN KJ, CLARKE NW AND MOORE JV. 2001. Photodynamic therapy for superficial bladder cancer. Expert Rev Anticancer Ther 1: 523-530.

SHELDON RA. 1994. Metalloporphyrins in catalytic oxidation. New York: Marcel Dekker.

SHEMIN D AND RUSSELL CS. 1953. $\delta$-Aminolevulinic Acid, Its Role In The Biosynthesis Of Porphyrins And Purines1. J Am Chem Soc 75: 4873-4874.

SIDOROFF A. 2014. Photodynamic Therapy in Dermatology. In: Hamblin MR and Huang YY (Eds), Handbook of Photomedicine. Boca Raton, Florida: CRC, p. 465-474.

SILVA AMG, TOMÉ AC, NEVES MGPMS, SILVA AMS AND CAVALEIRO JAS. 1999. meso-Tetraarylporphyrins as dipolarophiles in 1,3-dipolar cycloaddition reactions. Chem Commun, p. 1767-1768.

SILVA AMG, TOMÉ AC, NEVES MGPMS, SILVA AMS AND CAVALEIRO JAS. 2005. 1,3-Dipolar Cycloaddition Reactions of Porphyrins with Azomethine Ylides. J Org Chem 70: 2306-2314.

SILVA JN ET AL. 2006. Enhancement of the photodynamic activity of tri-cationic porphyrins towards proliferating keratinocytes by conjugation to poly-S-lysine. Photoch Photobio Sci 5: 126-133.

SILVA JN ET AL. 2010. Chain-dependent photocytotoxicity of tricationic porphyrin conjugates and related mechanisms of cell death in proliferating human skin keratinocytes. Biochem Pharmacol 80: 1373-1385.

SILVA S, PEREIRA PMR, SILVA P, PAZ FAA, FAUSTINO MAF, CAVALEIRO JAS AND TOME JPC. 2012. Porphyrin and phthalocyanine glycodendritic conjugates: synthesis, photophysical and photochemical properties. Chem Commun 48: 3608-3610.

SIMÕES MP, PIRES SMG, NEVES MGPMS AND CAVALEIRO JAS. 2016. Oxidative Transformations of Organic Compounds Mediated by Metalloporphyrins as Catalysts. In: Kadish KM, Smith KM and Guilard R (Eds), Handbook of Porphyrin Science: World Scientific Publishing, p. 197-306.

SIMON-ASSMANN P, LEBERQUIER C, MOLTO N, UEZATO T, BOUZIGES F AND KEDINGER M. 1994. Adhesive properties and integrin expression profiles of two colonic cancer populations differing by their spreading on laminin. J Cell Sci 107: 577-587.

SOARES ARM ET AL. 2012. Glycophthalocyanines as Photosensitizers for Triggering Mitotic Catastrophe and Apoptosis in Cancer Cells. Chem Res Toxicol 25: 940-951.

SOARES ARM, TOMÉ JPC, NEVES MGPMS, TOMÉ AC, CAVALEIRO JAS AND TORRES T. 2009. Synthesis of water-soluble phthalocyanines bearing four or eight d-galactose units. Carbohyd Res 344: 507-510.

SONCIN M, FABRIS C, FANTETTI L, DEI D, RONCUCCI G AND JORI G. 2004. Photodynamic therapy with a cationic phthalocyanine: A new antimicrobial approach to infectious diseases. Int J Antimicrob Agent 24: S205-S206.

SORTINO S, MAZZAGLIA A, MONSÙ SCOLARO L, MARINO MERLO F, VALVERI V AND SCIORTINO MT. 2006. Nanoparticles of cationic amphiphilic cyclodextrins entangling anionic porphyrins as carrier-sensitizer system in photodynamic cancer therapy. Biomaterials 27: 42564265.

SUN T, ZHANG YS, PANG B, HYUN DC, YANG M AND XIA Y. 2014. Engineered Nanoparticles for Drug Delivery in Cancer Therapy. Angew Chem Int Ed 53: 12320-12364.

SUTTON JM, CLARKE OJ, FERNANDEZ N AND BOYLE RW. 2002. Porphyrin, Chlorin, and Bacteriochlorin Isothiocyanates: Useful Reagents for the Synthesis of Photoactive Bioconjugates. Bioconjugate Chem 13: 249263.

TOME JPC, NEVES M, TOME AC, CAVALEIRO JAS, SONCIN M, MAGARAGGIA M, FERRO S AND JORI G. 2004. Synthesis and antibacterial activity of new polyS-lysine-porphyrin conjugates. J Med Chem 47: 66496652.

VAN ROY F AND BERX G. 2008. The cell-cell adhesion molecule E-cadherin. Cell Mol Life Sci 65: 3756-3788.

VAN VLERKEN LE, VYAS TK AND AMIJI MM. 2007. Poly(ethylene glycol)-modified Nanocarriers for Tumortargeted and Intracellular Delivery. Pharm Res 24: 1405 1414.

WALDMANN TA. 2003. Immunotherapy: past, present and future. Nat Med 9: 269-277.

WÖHRLE D, HIRTH A, BOGDAHN-RAI T, SCHNURPFEIL G AND SHOPOVA M. 1998. Photodynamic therapy of cancer: Second and third generations of photosensitizers. Russ Chem B 47: 807-816.

WOODBURN KW, BELLINGER GCA, PHILLIPS DR AND REISS JA. 1992. Synthesis Of Porphyrins Derived From The Amidation Of Protoporphyrin-Ix For Use As Potential Chemotherapeutic-Agents. Aust J Chem 45: 1745-1751.

XU Z AND SWAVEY S. 2011. Photoinduced DNA binding of a multi-metallic $(\mathrm{Cu}(\mathrm{II}) / \mathrm{Ru}(\mathrm{II}) / \mathrm{Pt}(\mathrm{II}))$ porphyrin complex. Inorg Chem Commun 14: 882-883.

YANG YM, REN L AND WANG HJ. 2017. Strategies in the design of gold nanoparticles for intracellular targeting: opportunities and challenges. Ther Deliv 8: 879-898.

ZHENG X AND PANDEY RK. 2008. Porphyrin-Carbohydrate Conjugates: Impact of Carbohydrate Moieties in Photodynamic Therapy (PDT). Anticancer Agents Med Chem 8: 241-268.

ZHOU Y, LIANG X AND DAI Z. 2016. Porphyrin-loaded nanoparticles for cancer theranostics. Nanoscale 8: 1239412405. 